\title{
Competition in the Cultural Sector: Handicrafts and the Rise of the Trade Fair in British Mandate Palestine
}

\author{
Nisa Ari
}

In the first week of July 1933, the First National Arab Fair opened in Jerusalem, filling the cavernous foyer and pristine rooms of the luxurious Palace Hotel on Mamilla Road (Fig. 1). Populating the first two floors of the hotel, the fair featured industrial, agricultural and artisanal wares from Palestine, Syria, Egypt, Lebanon and Iraq, occupying approximately sixty rooms with nearly one hundred exhibitors selling handicrafts (textiles, pottery and woodwork), food stuffs (chocolate, candy, jam, salt and olive oil), home goods (soap, furniture, carpets and perfume) and clothing (socks, hosiery and shoes). The exhibitors hailed from cities in Palestine including Jerusalem, Nablus, Haifa, Bethlehem and Ain Karim, as well as those outside of Palestine, including Beirut, Jounieh, Tripoli, Damascus, Aleppo, Baghdad, Cairo and Mecca. $^{1}$ Rather than be organised by country in separate pavilions or rooms, as was typical in nineteenth- and early twentieth-century world's fairs and colonial exhibitions, the exhibitors at the Arab Fair mixed with one another within each room, presenting a unified vision of Arab industry and

\footnotetext{
${ }^{1}$ The Arabic-language newspaper Al- Arab published a detailed description of the Arab Fair after it opened, including a full list of exhibitors and detailed floor plans. "The First Arab Fair," Al-'Arab, 15 July 1933.
}

N. Ari $(\bowtie)$

University of Houston, Houston, TX, USA

e-mail: nari@uh.edu

(C) The Author(s) 2021

K. Sanchez Summerer and S. Zananiri (eds.), European Cultural

Diplomacy and Arab Christians in Palestine, 1918-1948, https://doi.org/10.1007/978-3-030-55540-5_11 


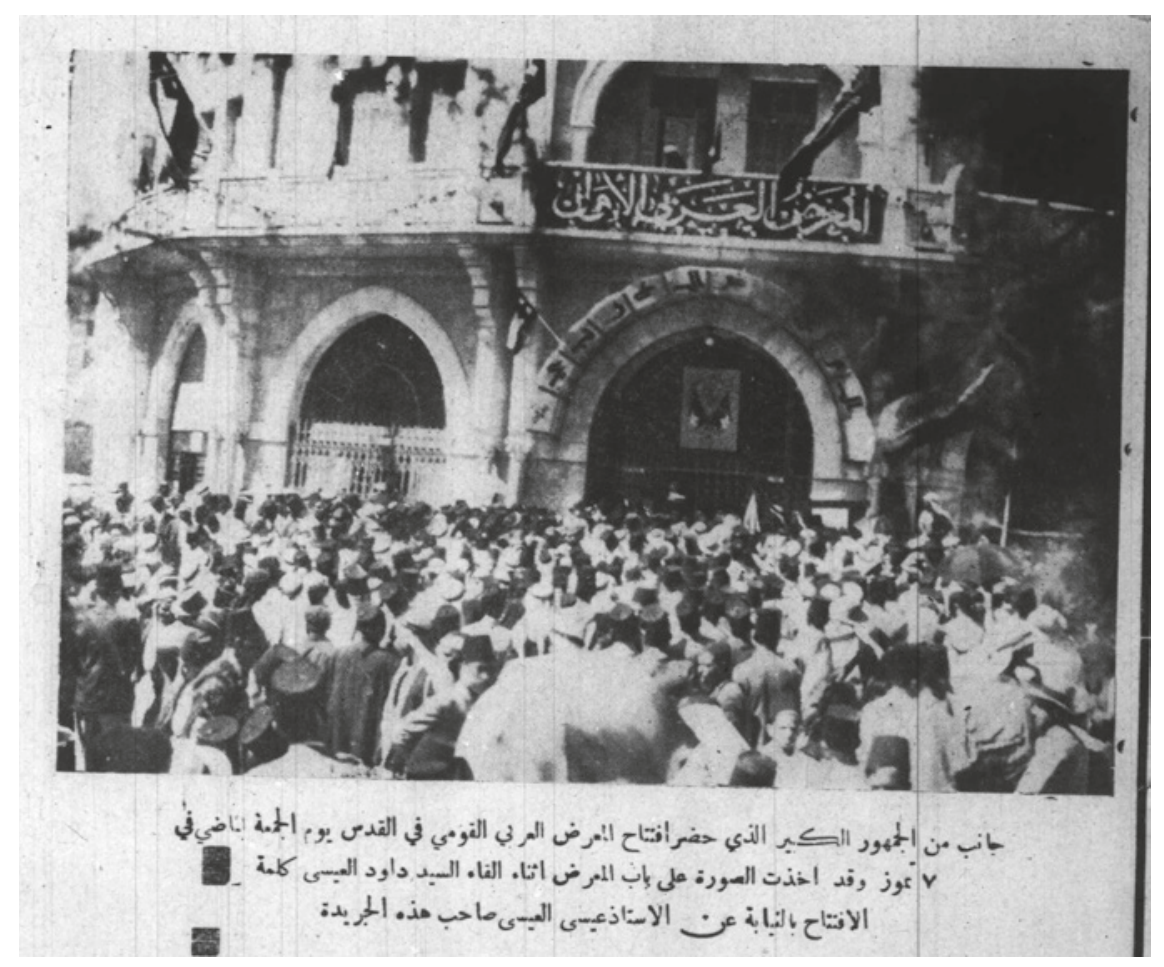

Fig. 1 “Opening of the National Arab Fair, 7 July 1933", Falastin, 16 July 1933; image courtesy of the Institute for Palestine Studies

culture. Within the hotel's capacious first floor atrium, a central exhibition, entitled “The World's Major Exhibition Products", brought together products from across the fair, surrounded by interior gardens housing multiple cafes for rest and conversation (Fig. 2).

The organisers of the Arab Fair included 'Issa al-'Issa (the Christian founder of the newspaper Falastin) and Ahmad Hilmi Pasha (the previous general director of Muslim awqaf in Palestine and founder of the Arab National Bank), along with a cadre of other Palestinian Christian and Muslim businessmen who believed in economic development as the core of political development. ${ }^{2}$ The First National Arab Fair (henceforth, "Arab Fair") underscored the valued role of artisanal, agricultural and industrial production in this mission.

\footnotetext{
${ }^{2}$ In her study of Palestinian economic unions of the 1930s, historian Sherene Seikaly identifies al- 'Issa and Ahmad Hilmi, among others, as "men of capital," Arab businessmen who positioned economic progress as crucial to constructing a "pan-Arab utopia of free trade, private property, and self-responsibility." Sherene Seikaly, Men of Capital: Scarcity and Economy in Mandate Palestine (Stanford, CA: Stanford University Press, 2016), 1, 37.
} 


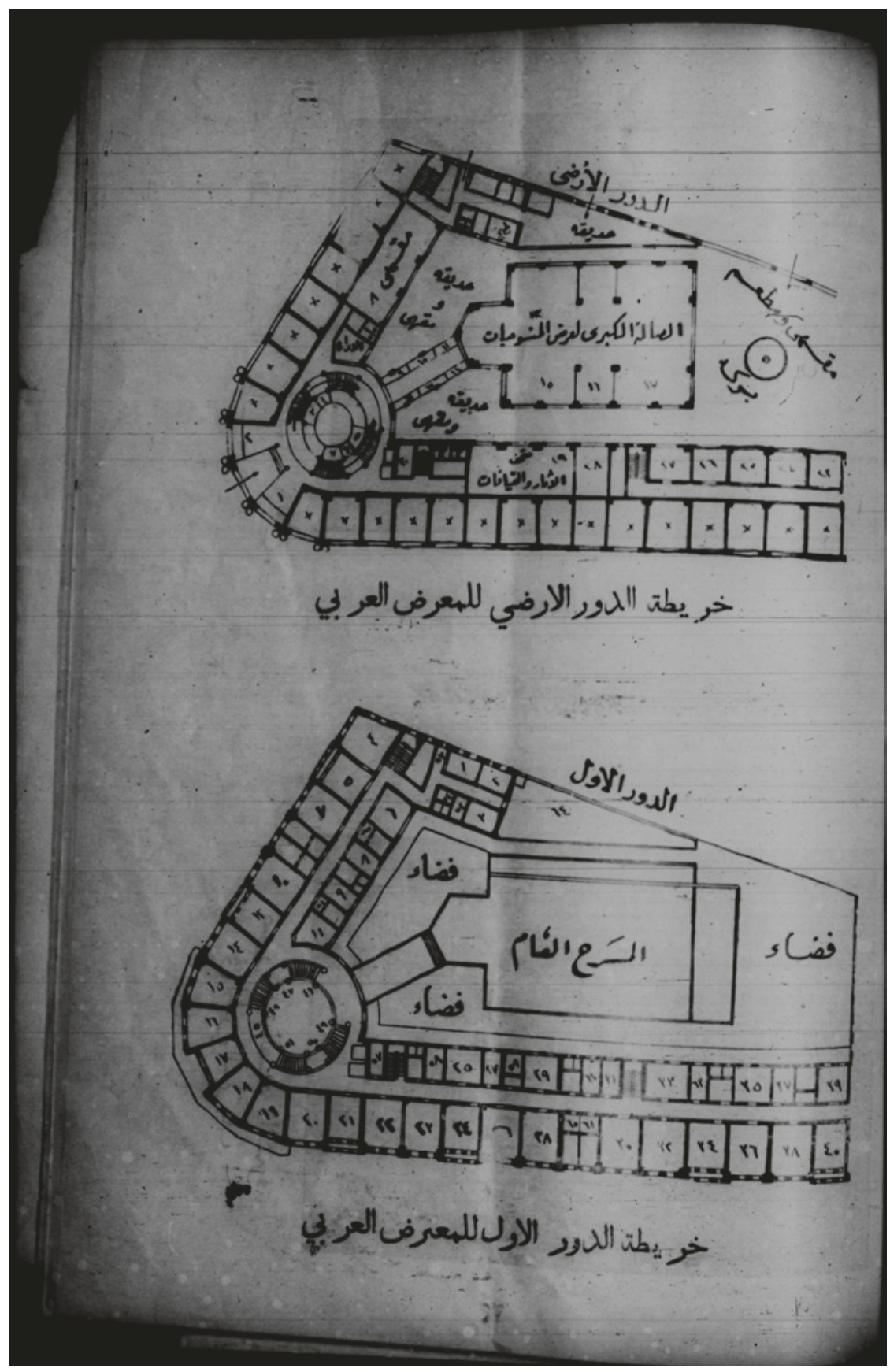

Fig. 2 "Exhibition Plan of the Arab Fair", Al-'Arab, 15 July 1933; image courtesy of the Institute for Palestine Studies 
Recent scholarship clarifies that the idea for an all-Arab Fair in Palestine was articulated as early as 1931, following a trip by al-'Issa to see the 1931 Paris Colonial Exhibition and a subsequent invitation to attend the 1932 Iraqi Agricultural and Industrial Exhibition in Baghdad. ${ }^{3}$ Yet, the stronger motive for staging an Arab Fair in 1933 came from a more direct impetus: as an aggressive response to the 1932 Levant Fair in Tel Aviv, organised by the Jewish trade organisation Mischar ve Taasia, and sponsored by the Municipality of Tel Aviv. Four smaller editions of the Levant Fair had occurred since 1924, but it was in 1932 that the Levant Fair organisers espoused their desire to become an "international" trade fair as a proof of concept for Zionist national ambitions. ${ }^{4}$ In that year, the Levant Fair garnered its official name, adopted the "Flying Camel" logo, and began to set its sights on building a permanent fairground in the space of 100,000 square metres on the Yarkon Peninsula, expanding the first Jewish city in Palestine to its most northwesterly point. ${ }^{5}$

The 1932 Levant Fair also greatly increased the number of international participants and included exhibitors from Egypt and Syria, neighbouring Arab countries under Mandate occupation. The presence of Arab businesses in a Jewish-organised trade fair stirred the Palestinian political elite to quick action. The organisers of the Arab Fair not only called for a boycott of the 1932 Levant Fair, which they saw as epitomising the economic and cultural colonisation of Palestine by Zionists, but they decided to stage their own trade fair by summoning a powerful internationalism of a different sort: pan-Arabism. The Arab Fair's catalogue, advertisements and signs were issued only in Arabic and only merchants from Arab countries were invited to exhibit their wares. While the Levant Fair extended its reach as a demonstration of the strength of the Zionist bureaucratic infrastructure and nationalist

\footnotetext{
${ }^{3}$ Nadi Abusaada, "Self-Portrait of a Nation: The Arab Exhibition in Mandate Jerusalem, 1931-34," Jerusalem Quarterly 77 (Spring 2019): 124-125. For a more detailed discussion than this essay will provide on the origins of the First National Arab Fair, especially as it was represented and discussed in Palestinian newspapers of the period, see Abusaada's full article as well as Nisa Ari, Cultural Mandates, Artistic Missions, and "The Welfare of Palestine," 1876-1948 (Ph.D. diss., Massachusetts Institute of Technology, 2019), 222-287.

${ }^{4}$ For example, at the ceremony to lay the foundation stone for the subsequent 1934 edition of the Levant Fair, Tel Aviv Mayor Meir Dizengoff extolled the union between the fair's zeal to become an international centre for trade and its ability to represent Jewish progress toward nationhood in Palestine: "This change from a sterile expanse into a throbbing centre of commerce and cultural activity is symbolic of those wider endeavours in this country which have already been responsible for reconstructional achievements which may, I think, be said to equal those of any other colonising undertaking of our time." Reinforcing (false) narratives which portrayed Palestine as barren - both socially and economically — before the mass migration of Jews to the region, Dizengoff's sentiments emphasised the importance of agricultural, urban, and now also industrial and commercial developments for the fulfilment of the settler colonial Zionist mission in Palestine. "Speech delivered by Mr. M. Dizengoff, O. B. E., Mayor of Tel Aviv, President of the Fair Committee, At the Laying of the Foundation Stone of the Levant Fair 1934 on August 16th 1933 [in English]," August 16, 1933, 2, L51 \351, Central Zionist Archive.

${ }^{5}$ C.f. the 1932 Levant Fair Poster, designed by Esther Berlin-Joel; The Palestine Poster Project Archives, http://www.palestineposterproject.org/poster/everybody-to-the-fair.
} 
ambitions, the Arab Fair intended to portray pan-Arab diversity as a marker of Palestinian unity and its own national future.

By 1933, then, the trade fair had become an effective site for the playing out of local, ethno-national politics within British Mandate Palestine. The purpose of this chapter is to sketch a lineage of trade fairs in Palestine in the decades immediately prior to the debut of the duelling "national" fairs of the 1930s - from one-room exhibitions hosted by Christian missionaries in the early 1900s to those assembled by British bureaucrats inside the Old City in the 1920s and 1930s - to investigate the roots of this typology. I contend that this history begins with the increase in religious missionary institutions in Palestine in the late nineteenth and early twentieth centuries. Christian institutions, in particular, were among the first to encourage the production, exhibition and sale of Palestinian handicrafts in order to solicit international support for their missionary work as early as the 1840s, efforts which were then mirrored by some of the earliest Zionist-sponsored institutions active in Palestine at the start of the 1900s, such as the Evelina de Rothschild School for Girls and the Bezalel School of Arts and Crafts, which hoped to foster the survival and growth of a Jewish community in Palestine. British bureaucrats, installed in Palestine once Britain was awarded the Mandate for Palestine in 1920, also adopted the format of the trade fair for political purposes, both abroad and at home. While their staging of Palestine's handicrafts abroad sought to solidify Britain's image as the harbinger of a modern Christian crusade in the post-Ottoman "Holy Land", trade fairs organised by British bureaucrats within Palestine served a radically different end: namely, to draw together Palestine's diverse ethno-religious, and urban and rural populations during a time of mounting political strife. By the time that the Levant Fair and the Arab Fair emerged as internationally-oriented trade fairs in the 1930s, in other words, the trade fair in Palestine was already coded as a space for garnering international support to enact local political change.

Undergirding this trajectory, I argue, was the formation of a "cultural sector" in Palestine - a conglomerate of institutions delimited by a distinct regional focus, furthering cultural development as part of both economic and political missions. My understanding of the cultural sector draws on its emergence following the Second World War as a UNESCO category, while questioning and assessing its historical evolution. ${ }^{6}$ As a ubiquitous, though often

\footnotetext{
${ }^{6}$ The UN formed after the Second World War in 1945 and established the specialised agency UNESCO in 1946. Initially, there were separate sections or divisions within UNESCO for the fields of libraries, museums, arts and letters. In 1948, these units were grouped under the newly created Department of Cultural Activities (CUA). In 1965 the units were reorganised into Sectors, thus creating the Social Sciences, Human Sciences and Culture Sector (SHC). UNESCO currently defines cultural and creative industries as "sectors of organised activity whose principal purpose is the production or reproduction, promotion, distribution and/or commercialisation of goods, services and activities of a cultural, artistic or heritage-related nature." http://www.unesco.org/new/en/santiago/culture/creative-industries/. See also Diana Crane, The Production of Culture: Media and the Urban Arts (Newbury Park, CA: Sage, 1992).
} 
perfunctory, term in the fields of art history, cultural studies, non-profit and humanitarian studies, and international relations, the concept of the cultural sector has yet to be historicised or positioned in relation to dominant frameworks of cultural diplomacy. Joseph Nye's definition of "soft power", which is predicated on nation-to-nation government relations, does not encompass those religiously-affiliated institutions which invested in promoting Palestine's cultural production for political action during the late Ottoman and British Mandate eras through trade fairs. ${ }^{7}$ Whereas "cultural internationalism", as distinguished by historian Akira Iriye, rests on the agency of individual cultural elites to promote "peace" and cross-national exchange through art and culture, the organisers behind trade fairs in Palestine kept their focus resolutely inward, to encourage change in the local politics around them. ${ }^{8}$

The concept of the cultural sector, on the other hand, makes space for understanding a variety of cultural institutions and actors, often in competition with one another, which engaged culture for immediate and localised political ends. ${ }^{9}$ Trade fairs and their organising infrastructures in British Mandate Palestine, as in the case of the Levant Fair and the Arab Fair, exemplify the type of institutions which contribute to a cultural sector. Moreover, this study's recognition of Christian missionary work, and religious charitable contributions more broadly, to the origins of the trade fair in Palestine and the Palestinian cultural sector contributes to historian Charlotte Faucher's recent call to investigate the historical relationship between cultural diplomacy and humanitarianism. ${ }^{10}$ By teaching and encouraging the production of handicrafts as a form of economic charity and humanitarian aid, and subsequently selling the objects as a way for donors to register their support for the religious mission, religious institutions created a new medium in Palestine through which to use culture as a form of diplomacy.

\section{Artistic Missions}

As precursors to the trade fair in Palestine, commercial displays of Palestinian handicrafts to support economic aims and particular ethno-religious communities originated among Christian missionary institutions in the 1840s and

\footnotetext{
${ }^{7}$ For Nye's construction of the term, see Joseph S. Nye, Bound to Lead: The Changing Nature of American Power (New York: Basic Books, 1990); Joseph S. Nye, "Soft Power," Foreign Policy no. 80 (1990): 153-171.

${ }^{8}$ Akira Iriye, Cultural Internationalism and World Order (Baltimore, MD: Johns Hopkins University Press, 1997).

${ }^{9}$ While the cultural sector is often considered alongside other putatively "soft" sectors in civil society, such as those supporting youth, women, education, and health, the cultural sector-like the financial sector or the business sector-tends equally to factionalise and receive funding for activities sponsored by local or international allies in support of particular politics.

${ }^{10}$ Charlotte Faucher, "Cultural Diplomacy and International Relations in Twentieth-Century Europe," Contemporary European History 25, no. 2 (2016): 381.
} 
permeated Jewish philanthropic activities by the early 1900s. The first craft workshops to be set up by religious pilgrims in Palestine may date as far back as the year 1347, when the Franciscan "Terra Sancta" mission in Bethlehem taught the arts of intaglio, wood carving and mother-of-pearl ornamentation, in addition to the Italian language, and liturgical and theoretical subjects to the Arab orphans under their care. ${ }^{11}$ While the records of the monastery show the Franciscans largely ceasing such handicraft production during the long duration of Ottoman rule, they revived their practices in the mid-nineteenth century as the surge in Euro-American religious tourism created a fresh market for their products. ${ }^{12}$ In addition to practicing these handicrafts among themselves for the practicality of furnishing monasteries with their own wares, the Franciscans taught their arts to many of Palestine's Arab Muslims (including orphans), with the hope of inspiring Catholic conversion while generating saleable handicrafts.

The Franciscan workshops were joined in the mid-nineteenth century by several new Christian missions to Palestine that were established under looser Ottoman laws. ${ }^{13}$ The German Protestant Templers, who had arrived in Palestine in the late 1860s, for instance, claimed not to use "traditional proselytism and denominational propaganda" to encourage conversions, but believed that by leading by example in work and trade they would be able to "influence the natives and stimulate them to imitation". ${ }^{14} \mathrm{By}$

${ }^{11}$ P. Bellarmino Bagatti O. F. M., "L'Industria Della Madreperla A Betlemme ("The Motherof-Pearl Industry in Bethlehem")," in Custodia Di Terra Santa, 1342-1942 (Jerusalem: Tipografia dei Padri Francescani, 1951), 135.

${ }^{12}$ The workshops experienced a few resurgences prior to that time: first, under the supervision of Father Bernardino Amico from 1593-97 and again, in 1740, when the Franciscans opened an "Arts and Trades" school in Jerusalem to complement the workshops in Bethlehem. P. Bellarmino Bagatti O. F. M., "L'Industria Della Madreperla A Betlemme"; "Handicrafts in Bethlehem," Custodia Terrae Sanctae, accessed September 13, 2018, http://www.bethlehem.custodia.org/default.asp?id=453; "The First Schools in the Shadows of the Sanctuaries," Custodia Terrae Sanctae, accessed September 13, 2018, http://www.custodia.org/default. asp?id $=506$.

${ }^{13}$ The 1839 Gülhane Edict, which recognised the basic rights of Ottoman citizens, was followed by a second edict, the 1856 Reformation Edict, extending those rights to non-Muslims and foreigners living in the Ottoman Empire. With this legal change in status, investors, bankers, and merchants began settling in the Ottoman territories in larger numbers, and in 1867 foreigners were granted the right to hold property. In Palestine, foreign missionaries especially purchased land and built structures, significantly altering the landscape after 1867.

${ }^{14}$ The Temple Society, The Temple Society in Palestine: To Interested Visitors of the Stand of the Society at the British Empire Exhibition Wembley (London: The Temple Society, 1924). The Templers were a group of Protestant families from southwest Germany. Their first settlement was in Haifa (1868) and they established additional communities in Jaffa (1869), Sarona (1871), Jerusalem (1873), Wilhelma (1902, today known as Bnei Atarot), and Bethlehem (1905). For more on the history of the German Templers in Palestine, see Alex Carmel, "The German Settlers in Palestine and Their Relations with the Local Arab Population and the Jewish Community, 1868-1918," in Studies on Palestine During the Ottoman Period, ed. Moshe Ma'oz (Jerusalem: Magnes Press, 1975), 442-465. 
excelling at all forms of handicrafts, from carpentry to baking, the Templers trusted that they could both sustain themselves in Palestine and provoke Jews and Muslims to turn towards Christianity, avoiding any direct proselytising to Muslims which was forbidden under Ottoman law.

More common among Christian missionaries in Palestine, however, was the opening of workshops for artisanal handicrafts as centres for conversion, similar to the Franciscan workshops. ${ }^{15}$ Most notable among them was the "House of Industry" opened by the Anglican Protestants of the London Jews' Society (LJS) in $1843 .{ }^{16}$ The LJS derived its name from the target of its conversions (as it hoped to convert Jews to Christianity), and the House of Industry was intended to combine their supreme mission with practicality. Originating in Ireland to discourage indiscriminate almsgiving, "houses of industry" and "workhouses" combined religious charity with the provision of training and a vocation to the destitute. ${ }^{17}$ Based on this model, the LJS' House of Industry similarly recruited poor Jewish men to train in carpentry, shoemaking, printing, and the production of popular souvenirs, such as olivewood boxes, tables and carved wooden covers for photograph albums, as seen in a photograph of the workroom from the late 1800s (Fig. 3).

While the House of Industry focused on training men, the LJS engaged Jewish women through "visiting societies" and "working parties", socially

\footnotetext{
${ }^{15}$ While my focus for this section will be on the LJS and the Evelina de Rothschild School for Girls, several other Anglican missionary and Jewish schools operated in Jerusalem at the same time, offering a combination of academic and artisanal training. Most notable among them were the woodworking workshop inside the Schneller Orphanage (established 1860 by German Protestants), the trade school of the Alliance Israélite Universelle (established 1882 by French Jews), and the embroidery and dress-making workshops inside Schmidt's Girls College (opened in 1886 by German Protestants for Arab Muslims and Christians). For more on these schools and others, see Paul Silberman, "An Investigation of the Schools Operated by the Alliance Israelite Universelle from 1862 to 1940" (PhD diss., New York University, 1973); H. L. Murre-van den Berg, ed., New Faith in Ancient Lands: Western Missions in the Middle East in the Nineteenth and Early Twentieth Centuries (Leiden and Boston: Brill, 2006); Norbert Friedrich, Uwe Kaminsky, and Roland Löffler, eds., The Social Dimension of Christian Missions in the Middle East: Historical Studies of the 19th and 20th Centuries (Stuttgart: Steiner, 2010); Seth Frantzman, "Education and Empowerment: Lessons and History of the Christian Education Network in Israel and Palestine," Digest of Middle East Studies 20, no. 2 (Fall 2011): 186-201.

${ }^{16}$ The British consulate was the first European consulate to open in Jerusalem in 1838-39, when Palestine was still under the control of the Egyptian ruler Muhammad Ali Pasha (from 1831-40). The LJS's inaugural project in Palestine was to erect Christ Church, the first modern church to be built in Palestine since the Crusades. Reflecting the importance of artisanal training in the overall mission of the LJS, the second major project was the establishment of the House of Industry, opened soon thereafter, in 1843. Kelvin Crombie, For the Love of Zion: Christian Witness and the Restoration of Israel (London: Hodder \& Stoughton, 1991), 4, 61-62.

${ }^{17}$ Catherine Cox, "Health and Welfare, 1750-2000," in The Cambridge Social History of Modern Ireland, eds. Eugenio F. Biagini and Mary E. Daly (Cambridge: Cambridge University Press, 2017), 262.
} 


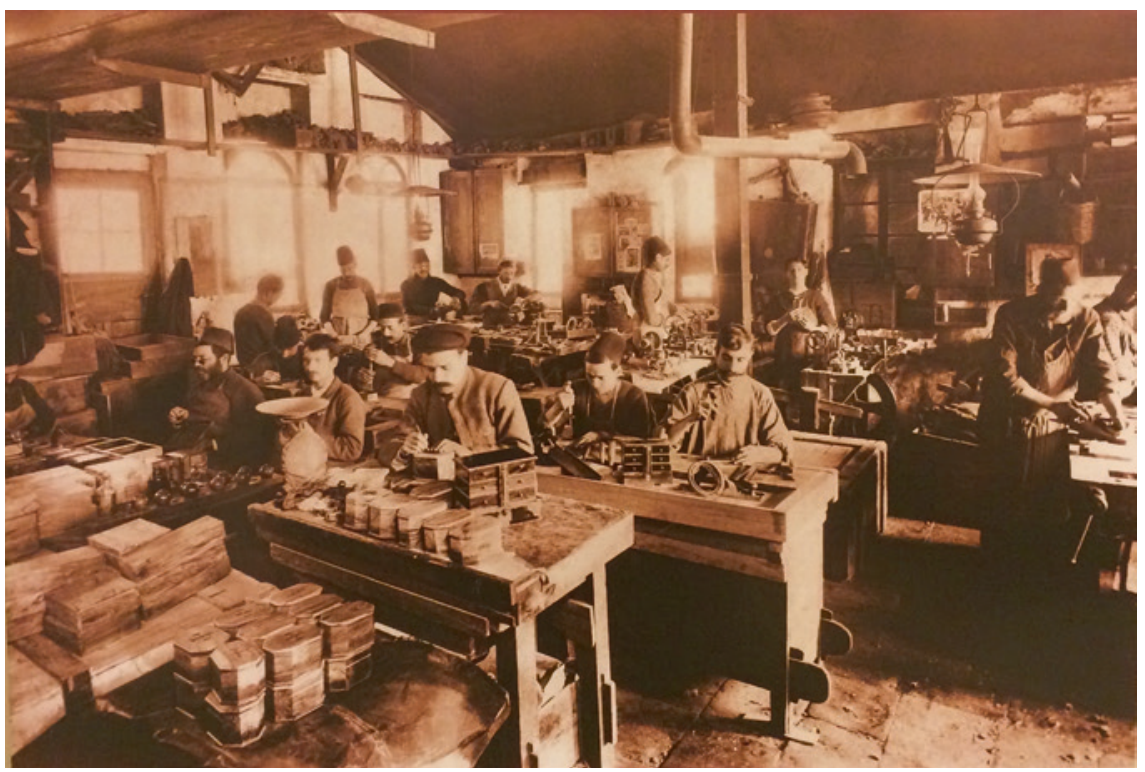

Fig. 3 Photographer unknown, "Interior view of the LJS' House of Industry", c. 1890-1914; image courtesy of the Conrad Schick Library and Archive

acceptable forms of female charity imported from Britain. ${ }^{18}$ Visiting societies, which aided indigent Jewish women in the privacy of their own homes, were sensitive to cultural notions of propriety which discouraged female presence in public space. ${ }^{19}$ Similar to the House of Industry, visiting societies combined evangelisation (Bible reading, distribution of religious texts and sermonising) with customary female work, such as sewing, weaving, and embroidery. The Jewesses Institute established in 1848 by Caroline Cooper, a Protestant missionary in Palestine, became the most visible and successful of these ventures. ${ }^{20}$ Hosting "working parties" for women outside the home, Cooper's innovative enterprise separated women's work from the patriarchal

\footnotetext{
${ }^{18}$ Structured to avoid creating dependent clients, the LJS' House of Industry and women's visiting societies also targeted the Jewish community's historic reliance on diasporic Jewish money, otherwise known as chaluka, which had been financing parts of the yishuv in Palestine for decades. For more on charity as a central concept in Judaism, see Gregg Gardner, The Origins of Organised Charity in Rabbinic Judaism (New York: Cambridge University Press, 2015).

${ }^{19}$ At the same time, these societies manifested Christian ideals of "visitation," humility, and service. Billie Melman, Women's Orients: English Women and the Middle East, 1718-1918: Sexuality, Religion and Work (Ann Arbor: University of Michigan Press, 1995), 180.

${ }^{20}$ Other protestant visiting societies in Palestine included the Dorcas Society (1849), the Sarah Society (founded by the British Consul James Finn's wife, Elizabeth Ann Finn, in 1854), and the Benevolent Society for the Relief of Poor Jewish Women in Child Birth (1865). Ibid., 180-182.
} 


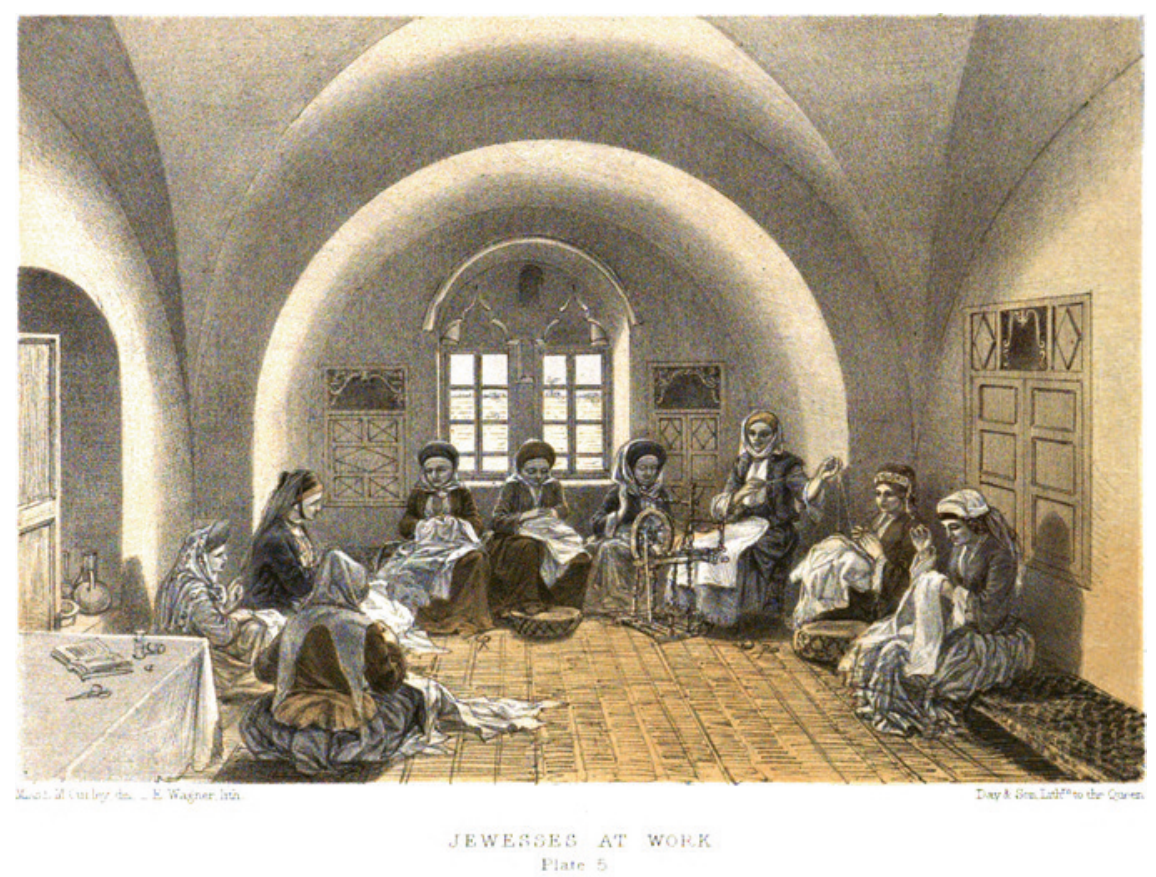

Fig. 4 Lucy Matilda Cubley, "Plate 5: Jewesses at Work", printed in Lucy Matilda Cubley, The Hills and Plains of Palestine (London: Day \& Son, 1860)

household environment. ${ }^{21}$ An illustration of the Jewesses Institute by Lucy Matilda Cubley for her published travelogue The Hills and Plains of Palestine (1860) shows women arranged in a semi-circle in a domed room, employed in several stages of yarn production and embroidery: picking, spinning, and stitching $^{22}$ (Figure 4 ).

The open book featured in the front left corner of the drawing is perhaps a set of sermons to be read to the women while they work, or maybe a pattern book or instructional aid. For Protestant missions in the Middle East, where due to cultural conventions "women could only be reached by women",

\footnotetext{
${ }^{21}$ I have not yet been able to pinpoint the precise location of Cooper's Jewesses Institute. Melman's account of the Jewesses Institute states that the meetings took place outside of domestic homes, but she does not describe the location. Yaron Perry's book on British missionaries in Palestine describes meetings of the Jewesses Institute as taking place in Church society buildings inside the Old City in 1891, but this was long after Cooper's death and therefore does not strongly correlate to where she may have hosted meetings during her lifetime. Ibid., 184; Yaron Perry, British Mission to the Jews in Nineteenth-Century Palestine (London: Routledge, 2003), 149.
}

${ }^{22}$ Lucy Matilda Cubley, The Hills and Plains of Palestine (London: Day \& Son, 1860). 
female missionaries played a vital role in the evangelical movement. ${ }^{23}$ Cooper's career underscored the secondary, and arguably much more successful, role such female missionaries played in intensifying handicraft production and in the modernisation of the domestic economy for Jewish women. ${ }^{24}$

A fundamental component of both the LJS' House of Industry and Caroline Cooper's Jewesses Institute was the operation of stores to sell their wares within Palestine-forerunners to the trade fairs which would come to dot Palestine's terrain throughout the first decades of the 1900s. While well-established Palestinian family workshops and souvenir shops existed throughout Palestine's major cities, like the Zachariah family souvenir shop in Jerusalem and the Zoughbi family mother-of-pearl workshop and store in Bethlehem, the proceeds from those sales were a direct exchange of money for goods, where the money supported the community of artisans and the further production of handicrafts. ${ }^{25}$ In the case of the early showcases for handicrafts made within Christian missionary workshops, there was an additional, explicit exchange of money not just for goods, but for the ideological support of Christian efforts in Palestine. Through this aspect of the interaction, one can glimpse the emergence of a cultural sector.

The House of Industry store was initially placed within a stone building abutting the entrance gate of the LJS compound, opening out towards the main street which proceeded into the Old City from Jaffa Gate (Fig. 5). Marketing itself as the "L.J.S. Industrial Depot", the hand-painted sign above the store's entrance advertised the "carpentry, turnery, printing, and bookbinding workshops" within, promising a variety of wares for sale. The proceeds from the sales would, in large part, directly finance the work of the LJS. Both physically and figuratively, the LJS' House of Industry store was the initial conduit through which travellers would come to know-and, ideally, financially support - the missionary work of the LJS in Palestine. Similarly, Caroline Cooper opened a small store to support the vocational programme of the Jewesses Institute. Cooper gained notoriety especially among female missionaries and tourists for the significant inroads her institute made in bringing Palestine's Jewish women into contact with Christian mores.

\footnotetext{
${ }^{23}$ Inger Marie Okkenhaug, The Quality of Heroic Living, of High Endeavour and Adventure: Anglican Mission, Women, and Education in Palestine, 1888-1948 (Leiden and Boston: Brill, 2002), xxii.

${ }^{24}$ Melman, Women's Orients, 184.

${ }^{25}$ The collector and historian George al Ama has made several recent discoveries of late nineteenth- and early twentieth-century artworks and handicrafts sold by the late Farah Zacharia, owner of the Zacharia souvenir shop in the vicinity of the Church of the Holy Sepulchre in Jerusalem's Old City. For more on Bishara and Yousef Zoughbi's mother-of-pearl and olivewood workshop in Bethlehem, which opened in 1876, see Enrique Yidi Daccarett, Karen David Daccarett, and Martha Lizcano Angarita, El Arte Palestino de Tallar el Nácar: Una Aproximación a Su Estudio Desde el Caribe Colombiano - "The Palestinian Art of Mother-ofPearl Carving: An Approach to Its Study from the Colombian Caribbean" (Bogotá: Panamericana Formas e Impresos, 2005).
} 


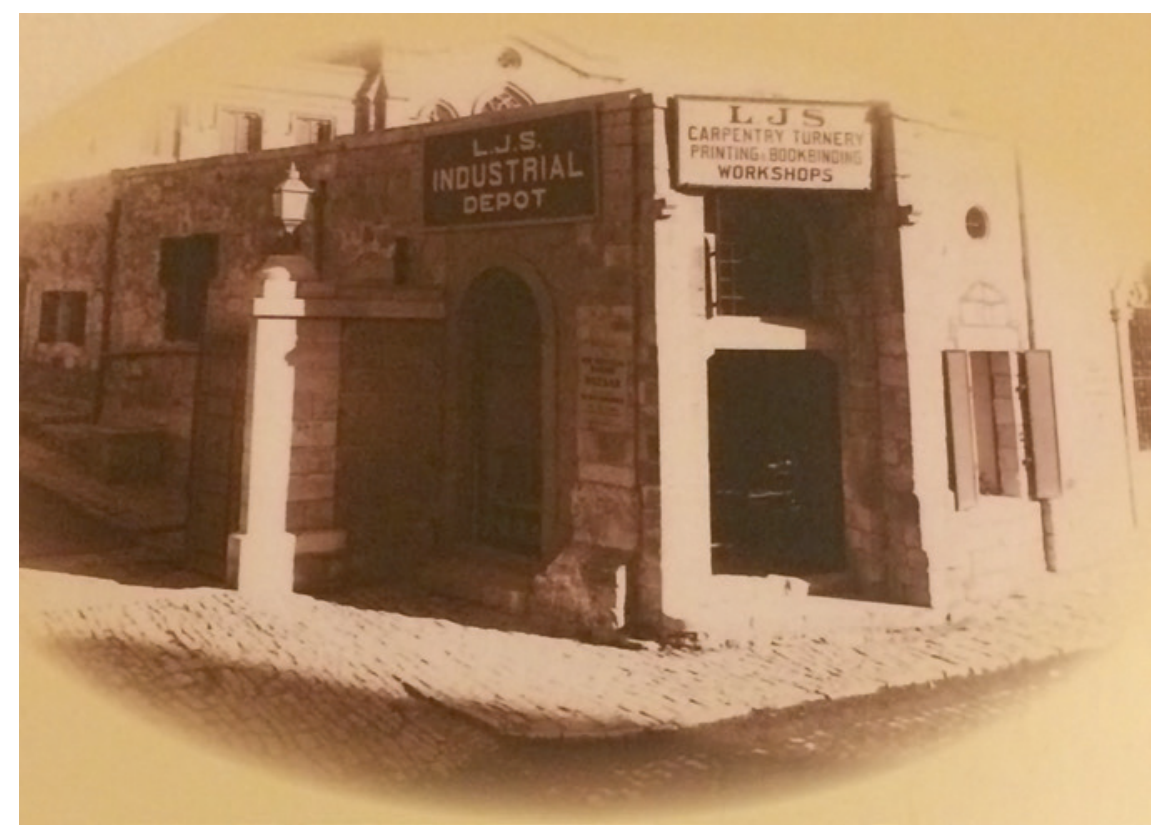

Fig. 5 Photographer unknown, "Exterior view of the LJS' House of Industry Store", c. 1930; image courtesy of the Conrad Schick Library and Archive

The Jewesses Institute became, according to historian Billie Melman, "a showcase of missionary work, a tourist attraction, on the map of every evangelical traveler", as Cubley's description and illustration of the institute in her popular travelogue attested. ${ }^{26}$ Cooper bequeathed her institute and small store to the LJS upon her death in 1859 , where it continued to run with its own vocational school, a girls' day school, and a commercial bazaar, described as "a small enterprise which employed Jewish women in handicrafts, the products being sold in Palestine and in countries abroad". ${ }^{27}$ Through the efforts of Palestine's nineteenth-century Christian organisations, commercial displays of Palestinian handicrafts - at home and, increasingly, abroadacquired an underlying ideological aspect.

Exhibitions staged abroad by Jewish philanthropic societies in the early 1900s further highlighted how handicrafts could function as repositories for international charitable givers-specifically, donors who hoped to contribute to the survival of poor Jews in Palestine during the precarious period of late Ottoman-era instability and the increasing persecution of Jews in Europe and Russia. The Evelina de Rothschild School for Girls - supported through the charity of the Jewish-German Rothschild family-excelled at marketing the

${ }^{26}$ Melman, Women's Orients, 185.

${ }^{27}$ Perry, British Mission to the Jews in Nineteenth-Century Palestine, 119. 
students' handicraft products in Jewish trade fairs abroad and provides an apt example. The Evelina School's headmistress from 1900-1945, Annie Landau, adamantly opposed the chaluka system, viewing it as a "degrading charity.... cancer eating away at the vitals of Jerusalem". ${ }^{28}$ Her creation of a lacemaking atelier and, later, millinery and dress workshops in the school provided job opportunities for the Jewish girls, where they were paid "five to twenty francs per month and received one hot meal a day as well as additional lessons in various subjects". ${ }^{29}$ To increase sales within Palestine, the Evelina School had adapted its designs to local needs, for instance by gaining commissions from the officers of the Turkish garrison in Jerusalem to make epaulettes with the embroidered words of al-Quds es-sharif ("The Holy, Noble place", the name for Jerusalem in Islamic texts) in Aleppine pure silver thread on red cloth. ${ }^{30}$

For sales abroad, the school focused on producing fancy embroidered articles as fashionable export goods for European buyers and as religiously themed Jewish goods for Jewish buyers all over the world. By 1910, the Evelina School's embroidery and lace works had been shipped out for sale in a Parisian shop, commissioned by Berlin department stores requesting "lace-trimmed handkerchiefs and dress trimmings", and were coveted in Amsterdam where the city's clientele desired simple dresses designed "to be comfortable, healthy, and beautiful". ${ }^{31}$ By 1914, the Evelina School's workshops had also produced ornamental synagogue curtains and Torah mantles for Jewish communities from Australia to Hungary and continued to receive individual lace orders from wealthy female clients in France, England, Switzerland and the US. ${ }^{32}$ The Evelina School's products not only included traditional Palestinian patterns or religious symbols, but likely incorporated popular Euro-American designs in order to appeal to a wide buying public outside Palestine.

By the early 1900s, the Evelina School contributed its wares to exhibitions hosted by European and American Jewish charities in order to expose the world to the needs of Palestine's Jewry and raise funds for its survival. Such exhibitions, like the one hosted by the Anglo-Jewish Association in Vienna in 1904 and an exhibition of Jewish handicrafts from Palestine in the Hague in 1907, were met with financial success. All articles of embroidery

\footnotetext{
${ }^{28}$ Annie Landau quoted from Anglo-Jewish Association, Thirty-Third Annual Report, 190304, 57-59 in Laura S. Schor, The Best School in Jerusalem: Annie Landau's School for Girls, 19001960 (Waltham, MA: Brandeis University Press, 2013), 61.

${ }^{29}$ Ibid., 62 .

${ }^{30} \mathrm{Ibid}$., 70. As a by-product of such training in missionary schools, providing needlework and embroidery services for soldiers continued to be an activity of women and girls in Palestine after the war. Charles Robert Ashbee, upon arrival to Palestine in 1918, reported that Arab women and girls were often found "hanging about the camps after the [British] soldiers" looking for work and materials. C. R. Ashbee, "Report by Mr. C. R. Ashbee on the Arts and Crafts of Jerusalem and District" (August 1918), 28, CRA/21/1, King's College Archives.

${ }^{31}$ Schor, The Best School in Jerusalem, 70.

${ }^{32}$ Ibid., 76-77.
} 
and handmade lace sent by the Evelina School to the 1904 Vienna exhibition, for example, sold immediately to an eager public, and Queen Wilhelmina of the Netherlands was evidently so impressed with the school's display in the Hague that she purchased some items for her own collection. ${ }^{33}$

In promoting the work of specific communities (in this case, the Jewish community) in Palestine, such exhibitions began to take on more explicitly political dimensions. The 1907 exhibition in the Hague, for instance, occurred as part of the meeting of the eighth Zionist Congress. That Queen Wilhelmina purchased an object made by the young Jewish students of the Evelina School may have indicated a diplomatic gesture of support for the Zionist movement in Palestine. ${ }^{34}$ The "Palestine Exhibition and Bazaar" held in London in 1912, another example of an exhibition hosted by the Anglo-Jewish Association, also articulated goals in line with Zionism. While on the surface the exhibition was a fundraiser to directly benefit the Evelina School and the newly formed Bezalel School of Arts and Crafts, the organisers' stated aim also included the more broad desire "to secure...the attention and active support of the Jewish community in England" for Jewish activity in Palestine. ${ }^{35}$ Within the delicate items on display, made of lace, copper, wool and silver filigree, was thus embedded a rallying cry to prompt English Jews to nurture the communal—and increasingly political—advancement of their brethren in Palestine. While the term "Zionism" was not used explicitly in the exhibition's promotional materials, the primary organisers of the 1912 exhibition, Cecil Franklin, Cyril Picciotto, and Leonard Stein, as well as many of the exhibition's patrons, were active members of London's Zionist associations. ${ }^{36}$ Moreover, the exhibition's organisers hoped that the status of the handicraft objects themselves would transform from religiously themed export goods to symbols of the Zionist movement in order to strengthen a

\footnotetext{
${ }^{33}$ Ibid., 59. In a pamphlet produced for the 1912 fundraiser exhibition for the school hosted by the Anglo-Jewish Association in London, Annie Landau reported: "I have received letters from Holland telling me that Queen Wilhelmina, when visiting the Palestinian Exhibition at the Hague, expressed her admiration of the lace and embroidery sent by us, and that she purchased some of it." For reference, see The Committee of the Palestine Exhibition and Bazaar, Awakening Palestine (London, 1912), 5.

${ }^{34}$ For more on the relationship between the Jewish community in the Netherlands and Dutch royal attitudes towards Jews, see Bart Wallet, "Dutch National Identity and Jewish International Solidarity: An Impossible Combination? Dutch Jewry and the Significance of the Damascus Affair (1840)," in The Dutch Intersection: The Jews and the Netherlands in Modern History, ed. Yosef Kaplan (Leiden and Boston: Brill, 2008): 319-330.

${ }^{35}$ The Committee of the Palestine Exhibition and Bazaar, Awakening Palestine, 3.

${ }^{36}$ For a discussion on Zionism in Picciotto's own words, see for example Jacob Alexander, Cyril M. Picciotto, and Leon Simon, Zionism and the Western Jew: A Symposium Read before the London Zionist League, on the 24th December, 1908 (London: Ginzburg, 1908). Stein, in particular, went on to serve in high-ranking positions in the World Zionist Organisation and the Jewish Agency for Palestine during the British Mandate period. For a brief biography on Stein, see "Stein, Leonard Jacques (1887-1973), Scholar and Zionist," Oxford Dictionary of National Biography, accessed April 1, 2019, https://doi.org/10.1093/ref:odnb/31717.
} 
Jewish ethno-national identity in Palestine: "Whether that art [the handicrafts of the Evelina School and Bezalel on view] is to be truly national depends upon the warmth of the encouragement it will receive when its aims and achievements are properly understood". ${ }^{37}$ In this context-one that would presage future trends-handicrafts, initially created to support Jewish "livelihood" through the auspices of a religious charitable institution, later existed to sway the opinion of donors towards the goals of a particular political movement, which in this case was Zionism. ${ }^{38}$

\section{The Trade Fair During the British Mandate}

From the Jewesses Institute's commercial store launched in 1850s Jerusalem to the 1912 "Palestine Exhibition and Bazaar" in London, exhibitions galvanised financial giving to religious and increasingly political causes in Palestine through the purchases of handicrafts. These early exhibitions positioned the space of display as one of sectarian solidarity and handicraft objects as objects of political persuasion. The Bezalel School of Arts and Crafts, which received its initial financial support through German and Russian Jewish charities, frequently staged exhibitions abroad featuring its handicrafts to raise money for the school and support for the Zionist cause. From the US to Austria and South Africa, Bezalel's carpets, silver filigree work, copper inlay and woodwork were sold to solicit support for the Jewish Zionist movement in Palestine until the onset of the First World War temporarily halted their journey. ${ }^{39}$

${ }^{37}$ The Committee of the Palestine Exhibition and Bazaar, Awakening Palestine, 8. Emphasis mine.

${ }^{38}$ The use of exhibitions as Zionist fundraising efforts aligns with cultural historian Michael Berkowitz's conclusions regarding the relationship between Jewish fundraising and Zionism during this time: "In large part Zionism owed its surprising success to constructively integrating fundraising into the movement, which provided a means for Westernised Jews - those who were not conceived as Palestine's 'pioneers' - to participate in, and feel a full part of, the national movement." While in principle Zionism denigrated the idea of a Jewish diaspora, European and American Jews were needed to "bankroll" the movement, and such exhibitions and trade fairs provided a vehicle for their financial support. Michael Berkowitz, "Toward an Understanding of Fundraising, Philanthropy and Charity in Western Zionism, 1897-1933," Voluntas: International Journal of Voluntary and Nonprofit Organizations: Official Journal of the International Society for Third-Sector Research 7, no. 3 (1996): 247, 253-254.

${ }^{39}$ Proposed by the Lithuanian Jewish artist Boris Schatz at the Seventh Zionist Congress in Basel in 1905, Bezalel was an explicitly Zionist project that existed well before Zionists built their first kibbutz (Degania, 1909) or first university (Hebrew University, 1918) in Palestine. For more on the founding of Bezalel, its funding bodies, and the history of its exhibitions abroad see Nurit Shilo-Cohen, ed., Bezalel: Crafting a Jewish Style-The Art of Bezalel, 1906-1996 (New York: Jewish Museum, 1996); and Inka Bertz, "Trouble at the Bezalel: Conflicting Visions of Zionism and Art," in Nationalism, Zionism and Ethnic Mobilization of the Jews in 1900 and Beyond, ed. Michael Berkowitz (Leiden and Boston: Brill, 2004), 247-284. 
The trade fairs which emerged in Palestine during the British Mandate, under the direction of British bureaucratic agents, further defined the trade fair as a tool of cultural politics. After defeating Ottoman forces and occupying Palestine in December of 1917, British agents orchestrated exhibitions of regional handicrafts and industry, attaching a cultural component to their mission of redeeming and vivifying the so-called Holy Land. The earliest such exhibitions were guided by the Pro-Jerusalem Society (PJS), founded in 1918 by Jerusalem's first military governor Ronald Storrs and directed by Charles Robert Ashbee, a pioneer in the British arts and crafts movement. ${ }^{40} \mathrm{~A}$ shortlived cultural crusade of Storrs' design, the PJS' original charter stated that the society aimed to be the "creative" and "pacific" arm of the pre-colonial British military government. ${ }^{41}$ Maintaining its efforts through matching grants with private contributors, the PJS promised its international supporters that it would advance the welfare of Jerusalem's inhabitants through a dual focus on architectural preservation and the establishment of art galleries and cultural centres. ${ }^{42}$

While primarily remembered as the entity which altered the face of Jerusalem through requiring the use of blush-coloured "Jerusalem stone", the PJS also hosted the earliest trade exhibitions within the Old City. Making use of a few empty rooms within the Citadel inside Jaffa Gate, the PJS orchestrated three exhibitions of Palestine's handicraft industries between the years 1921-1922 to "help in the education of the community" and to stimulate the three major handicraft industries-weaving, ceramics, and glass - which Ashbee and Storrs hoped would contribute to the PJS's planned architectural restoration and building projects. ${ }^{43}$ More importantly, Ashbee clarified, he intended the exhibitions to pose significant questions regarding the future of Palestine's Jewish residents:

\footnotetext{
${ }^{40}$ For more on the life of $\mathrm{C}$. R. Ashbee and his involvement in the British Arts and Crafts movement, see Alan Crawford, C. R. Ashbee: Architect, Designer \& Romantic Socialist (New Haven: Yale University Press, 1985).

${ }^{41}$ C. R. Ashbee, "Pro-Jerusalem," The American Magazine of Art 12, no. 3 (1921): 99.

${ }^{42}$ While the term "matching grant," like "cultural sector," was not in use until several decades later, Ashbee described the Society's finances as such: "The Administration gives to the Society pound for pound of what it receives in subscriptions and donations...so that the income, exclusive of special grants for education or fresh subscriptions and donations, will for the current year be double that sum." Charles Robert Ashbee, ed., Jerusalem, 1920-1922: Being the Records of the Pro-Jerusalem Council during the Period of the British Military Administration (London: J. Murray, Published for the Council of the Pro-Jerusalem Society, 1924), 31.

${ }^{43}$ In addition to nurturing these crafts for restoration and other architectural works, Ashbee posed a political dimension to the PJS' encouragement of handicrafts: "This re-establishment of the crafts, even if looked at merely from the political point of view, is of vital importance in Palestine. [...] Work with the hands, the creative work, the work of the imagination applied to a man's personal labour, keeps men from empty political speculation. For every craftsman we create, we create also a potential citizen; for every craftsman we waste, we fashion a discontented effendi." Ibid., 29.
} 
The whole Zionist problem is involved in this, for it means the life of the Jewish colonies. Are they going to continue to be dependent on outside support? Will they develop mechanical power intelligently? Will they practise [agricultural] by-crafts, as the Palestinian peasant has done for thousands of years? Here are not only vital problems in the theory of civics, the Zionist question itself is involved, and the Mandate for Palestine. ${ }^{44}$

Ashbee's anxious questioning referenced the mandate's responsibility towards fostering a Jewish national home in Palestine, as outlined in the 1917 Balfour Declaration.

The organisation of the PJS' inaugural trade exhibition reflected Ashbee's concern, which was a display "in part town planning and the crafts encouraged by the Society, in part ancient Moslem art, in part modern Palestinian effort". 45 The section on "modern Palestinian effort" was primarily devoted to Jewish industrial and artistic advancements in Palestine, whereas Arab handicrafts were limited to displays of "ancient Moslem art" and the handicraft industries explicitly nurtured by the PJS, such as ceramic tilework for restorations to the Dome of the Rock, and weaving as part of Ashbee's "Jerusalem Looms" project. A total of 260 paintings and drawings, primarily from the recently formed Hebrew Union of Artists, joined the nearly 4000 handicrafts and utensils on view. ${ }^{46}$ The uneven display prompted Palestine's High Commissioner, Herbert Samuel, to express regret that the Muslim works were displayed mainly as "antiques". However, he used the occasion as an opportunity to speak on the perceived laggardly progress of Arab handicrafts when compared with the "modern" Jewish displays: "I hope our Muslim friends will not hesitate to follow suit [making modern furniture and housewares], and will participate more vigorously in future exhibitions". 47

Intended as a showcase of the PJS' early progress, the Citadel exhibitions simultaneously reinforced a vision of Palestinian handicrafts that equated Arab industry with Palestine's past and Jewish industry with Palestine's future. The second PJS exhibition, staged in 1922, underscored this impression by neatly dividing its displays into two categories: a traditional department and a modern department. The traditional section included home goods, ceramics, metal work, textiles, glass work and women's costumes from Ramallah, Hebron (al-Khalil), Bethlehem and Jerusalem. These were mainly the work of Arabs, with a small section for carpets made by a subsidiary workshop of the Bezalel School. The traditional section was seemingly the focus of the

\footnotetext{
${ }^{44}$ Ibid., 31 .

${ }^{45}$ Ibid., 30. A newspaper report on the exhibition clarified that there were specific sections devoted to Islamic art, architectural plans, international art, and a section for the recently formed Hebrew Union of Artists. Yigal Zalmona, The Tower of David Days: First Cultural Strife in Israel Art (Jerusalem: Tower of David Museum of the History of Jerusalem, 1991), 73.

${ }^{46}$ Zalmona, The Tower of David Days, 73.

${ }^{47}$ Ibid.
} 
exhibition's poster, a romantic image of a lone potter designed by the Jewish artist Ze'ev Raban. ${ }^{48}$

The modern department, on the other hand, favoured Jewish handicraft production, including soap from Haifa, brushes, leather goods from Jaffa, books and graphic works by the Jewish designer Yihieh Yedidia, and displays of wicker furniture by Arabs from the German Protestant Schneller Orphanage in Jerusalem and the Abu-Sheikh workshop in Beersheba. ${ }^{49}$ Despite Raban's poster marketing traditional handicrafts and the PJS' stated intention of balance among the Jewish and Arab displays, the teleological narrative within the exhibition's design suggested it was Jewish industry and handicrafts which were to dominate Palestine's future.

Perhaps it was unsurprising, then, when at the British Empire Exhibition of 1924 held in Wembley, London, the Palestine Pavilion hardly incorporated Arab-made Palestinian handicrafts. The British Empire Exhibition celebrated the reach of the Crown following World War I- "the British Empire in microcosm" as the official guide stated-and Palestine was featured in its own pavilion among those of the empire's many colonies and dependencies. ${ }^{50}$

While the primary emphasis of the colonial trade fair was on the "unbounded potentialities" and economic prowess created through the industrial, agricultural, cultural, and even ethnic bounty of the empire, the focus of the Palestine Pavilion was decidedly more reverent. ${ }^{51}$ "The country has not been annexed to the British Empire; we hold it as a trust", wrote High Commissioner Samuel in the pavilion's handbook. Noting the empire's conviction to afford equal rights to "all races and creeds" and remarking how the British found Palestine "derelict after centuries of misrule", the Palestine Pavilion was intended to convey how British rule in Palestine provided Christian redemption of the Holy Land from Ottoman neglect. ${ }^{52}$

The displays inside the Palestine Pavilion, which included British but also Zionist companies monetising Palestine's natural resources of oil, salt, stone, tobacco and other minerals and agricultural produce, conveyed the region's assets, but, as the handbook made clear, were meant primarily to indicate and enlist British support for "the progress which has been made since the

\footnotetext{
${ }^{48}$ Cf. poster for the 1922 Palestine Crafts and Industries Exhibition, designed by Ze'ev Raban, published by the Jerusalem Municipality; The Palestine Poster Project Archives, https://www. palestineposterproject.org/poster/palestine-crafts-and-industries.

${ }^{49}$ Ibid., $72-73$.

${ }^{50}$ British Empire Exhibition 1925 Official Guide (London: Fleetway Press, 1925), 23, Brent Archives.

${ }^{51}$ Ibid.

${ }^{52}$ Further text in the Palestine Pavilion handbook underscores the British desire to remake Palestine in its ancient, pre-Islamic image: "Here is evidence of the many-sided activities of the Government, of corporations, and of individuals...in revealing the ancient Palestine and in building the new." Sir Herbert Louis Samuel, "Introduction," Palestine Pavilion Handbook (London: Fleetway Press, 1925), 21-22, Brent Archives.
} 
British Government assumed responsibility". ${ }^{53}$ The handicrafts and ephemera on view-intricate wooden models of the Jewish Temple and drawings of the Dome of the Rock, pottery, toys, glassware, furniture, weaving, embroidery and unique souvenir boxes filled with Palestine's "sacred soil" (containing Palestinian wildflowers, water from the Jordan River, and earth from Mount Moriah) - covered a wide field of handicrafts and industries purportedly flourishing under mandate rule. ${ }^{54}$ The official guide located the origins of these crafts in a pre-Islamic period, "still maintained by both Arab and Jew in their primitive form, dating back in many cases to a remote antiquity", and presented the mandate government's desire to "promote in Palestine both an Arab and Jewish revival". ${ }^{55}$ In this spirit of parity, both Arab glassblowers from Hebron and Jewish filigree workers from Yemen, who had recently settled in Palestine, were scheduled to travel to Wembley to be on view and "at work" in the exhibition. However, due to financial constraints only the Yemenites managed to be on display, owing to Zionist sponsorship. ${ }^{56}$

Thus, in the end, the Palestine Pavilion at the 1924 British Empire Exhibition presented Palestine as a land touched most significantly by British and Zionist development, despite the handbook's pronouncements of equality and ethno-religious harmony. As the historian Nicolas Roberts underscores in his study of the Palestine Pavilion's organising committee, "the pavilion, like the country itself, was dominated by British and Zionist officials, the exclusion of the Arab population was not only inevitable but easy". ${ }^{57}$ The relative invisibility of Palestine's Arab-run industry on a world stage was made more stark by the continued prolific displays of Zionist activity in international trade fairs, which skyrocketed following the 1924 British Empire Exhibition. The most large-scale of these endeavours included the 1925 Palestine Vienna Exhibition, the 1933 Anglo-Palestine Exhibition in London, and Palestine pavilions at the 1934 Chicago World's Fair, and the 1939 New York World's Fair. The products for sale at the fairs-from Jaffa's oranges to

\footnotetext{
${ }^{53}$ Ibid., 109.

${ }^{54}$ Ibid. and Nicholas E. Roberts, "Palestine on Display: The Palestine Pavilion at the British Empire Exhibition of 1924," Arab Studies Journal 15, no. 1 (2007): 72.

55 Palestine Pavilion Handbook, 116, 21.

${ }^{56}$ Yemenite jewellers, sent as representatives of the Bezalel School of Arts and Crafts, were lauded in the Palestine Pavilion handbook for having "extended their outlook with more modern, but Jewish ideas...The result was a new style of art, which can no longer be described as purely Yemenite, but rather as Palestinian." Archival letters reveal that the jewellers were initially to be joined by Arab glassblowers from Hebron for the "Native Craftsmen at Work" display within the pavilion: "I take this opportunity to remind you that 2 Yemenite Jewellers are being sent to London for working during the whole period of the exhibition. They will leave for London together with the 3 Arab glassmakers of Hebron." Without Zionist financial support, however, bringing the glassblowers was "found impracticable." Ibid., 116; "Letter from the Secretary for Trade and Industry to Leonard Stein, WZO" 6 February 1924, S25 111024-9-12, Central Zionist Archive.
}

${ }^{57}$ Roberts, "Palestine on Display," 73. 
the "oriental" rugs and silver-filigreed Judaica produced by the workshops of the Bezalel School-were marketed to consumers as investments towards furthering the Jewish national movement in Palestine. Palestine, in these displays, was self-consciously and solely presented as a Jewish entity.

However, the history of the trade fair in British Mandate Palestine includes at least one attempt to reorient the format of the trade fair towards creating political and ethno-religious harmony between Jews and Arabs, rather than sowing disparity. In the 1930s, the British Mandate government appointed a Director of Technical Education, William Arnold Stewart. Stewart hoped to revive the use of the Citadel for exhibitions of artisanal handicrafts, with an approach reflective of the administration's need to quell the heightened tensions between Jews and Arabs in the wake of the watershed violence of the 1929 Wailing Wall Riots/al-Buraq Uprising. Stewart negated the widely held belief among British officials that Arabs lacked the skill or desire to excel in industry and handicraft production. ${ }^{58} \mathrm{He}$ framed the immediacy of his efforts in Palestine not in terms of the threat of the arrival of mechanised European industrial commodities, as was the case for instance in British-controlled India, but in terms of the competing Jewish labour force in Palestine ${ }^{59}$ :

The Arabs are up against very stiff competition with the Jewish Artisans, and they have every right to demand that Technical Training, of a high standard, shall be provided for them. [...] The theory that the Arab is not fitted for highly skilled technical work must be disproved by actual achievement. ${ }^{60}$

While several Arab-run political, commercial and educational institutions were in their incipient stages, there was no equivalent to the Zionist Organisation's centralised planning or financial support from abroad at that point, nor a school devoted to the study of traditional handicrafts or new industries. ${ }^{61}$ As expressed throughout his unpublished manuscript, Creative

\footnotetext{
${ }^{58}$ Given the jaunty nickname "Arts and Crafty Stewart," Stewart first arrived in the Middle East as the inspector of arts and crafts with the Egyptian Ministry of Education and later, became principal of the School of Arts in Crafts in Cairo (1911-1927) before arriving in Palestine. Trained primarily as a painter at the Royal College of Art in London, Stewart embodied the ethos of the arts and crafts movement as it had manifested in England and as it had developed and mutated through British colonial projects in the Middle East. Like Ashbee, Stewart believed that traditional processes of craft production and ancient workshop and guild structures were still active in these regions and viewed the Middle East as the ultimate example of and most fruitful landscape for enacting an arts and crafts pedagogy. For a biographical summary of Stewart's life, see Jaromir Malek, "Stewart, William Arnold (1882-1953)," Oxford Dictionary of National Biography (2004).

${ }^{59}$ Arindam Dutta, The Bureaucracy of Beauty: Design in the Age of Its Global Reproducibility (New York: Routledge, 2007), 19.

${ }^{60}$ W. A. Stewart, "Creative Work in Palestine: Technical and Crafts Education, 1918-1946" (n.d.), 129-130, Oxford University, Griffith Institute.

${ }^{61}$ The Arab Executive Committee (founded 1920), the Supreme Muslim Council (1922), and the Arab Higher Committee (1936) represented the main political bodies emerging out of rival family factions in the 1920s and 1930s. While these organisations helped to fund schools
} 
Work in Palestine, Stewart felt duty-bound to balance the scale in regard to Arab success in the handicrafts and technical industries.

In setting his task to equalise the handicraft industries between Jews and Arabs, Stewart identified two problems hindering his goal: the lack of technical education in government-run Arab schools and the purportedly inadequate space for the egalitarian display and sale of handicraft objects. Stewart complained about Jerusalem's limited exhibition spaces in his manuscript:

Some examples of craftswork were to be seen in the Store of the American Colony and in one or two shops in the Jaffa road, but in none of these was there a really representative selection of all Arab and Jewish crafts. ${ }^{62}$

Beyond the more enterprising souvenir shops along Jaffa Road, the Bezalel School also hosted frequent exhibitions of its work and Stewart hosted small displays of handicrafts from the government schools. ${ }^{63}$ However, following the few PJS attempts in the early 1920s, there had been no further effort to gather such disparate undertakings under one roof.

Like a local version of a world's fair, Stewart set about organising a local trade fair that would display handicrafts from every possible school, village and individual around the country he could find:

We collected carpets from Gaza, silk stuffs from Mejdal hand looms, cotton stuffs from the Alliance Israelite workshop, copper work from Nazareth, Bethlehem pearl and olive wood work, Yemenite Basket work and Embroideries, lace, jewelry, in fact anything and everything we could find that was useful and attractive. Peasant women brought in embroidered head shawls and could not understand why my wife selected those of old traditional stitch and design and rejected others decorated with swans, cupids, and harps taken from French cross-stitch pattern books. ${ }^{64}$

and religious institutions, and Arab-founded banks and business unions also formed during this period, there was no real equivalent to the Jewish Agency's comprehensive planning and institutional prowess, including the formation of special departments such as those for Economic Research or Agriculture. Roza El-Eini, Mandated Landscape: British Imperial Rule in Palestine, 1929-1948 (London; New York: Routledge, 2006), 22.

${ }^{62}$ Stewart, "Creative Work in Palestine," 57.

${ }^{63}$ In addition to graduation exhibitions for high schoolers and some small exhibitions of works by teachers, Stewart created a hybrid exhibition-competition for boys in the government Arab elementary schools. Each year, Stewart circulated the subject of the exhibition to the schools and the submitted entries were exhibited and judged by a set of officials from the architectural section of the Department of Public Works. The subjects ranged from the creation of objects, such as "a small Arabic table to be enriched with veneered inlay" (to be submitted alongside complete working drawings), to drawing tests, such as "a study in colour of Palestinian wild flowers" or "an illustration to the story of Joseph and his Brethren." Ibid., 120.

${ }^{64}$ Ibid., 57. 
Stewart brimmed with excitement over the local diversity of the artisans and the variety of media he was able to exhibit in a unified manner. Stewart's listing of the participants in the trade fair reveal his bias towards works with "traditional" designs and those produced in regionally specific media. Collecting "anything and everything", Stewart hoped to stimulate a local interest in and a market for all of Palestine's handicrafts, produced by Jews and Arabs. After hosting the exhibition for four years in a single room inside the Citadel, Stewart concluded that the exhibition's visibility successfully stimulated the migration of handicrafts from exhibition space to store window: "The object had been served; we had made a market for them and there seemed to be no further reason for competing with the shops". ${ }^{65}$

The Arts and Crafts Exhibition highlighted the guiding principle behind Stewart's most public endeavour in Palestine, to create a space-through the framework of the trade fair-in which Jews and Arabs could find common ground. He reflected on this position towards the end of his lengthy memoir, writing, "If Jews and Arabs could agree to work together, to be Palestinians and work for Palestine, they might succeed". ${ }^{66}$ The proclamation of this ethos illuminates the double meaning behind the title of Stewart's manuscript Creative Work in Palestine. Not only did he believe a strong technical education would serve as a form of labour, or "creative work" for Palestine's rural communities in financial need, but he harboured hope that culture, potentially through the format of an economically motivated trade fair, could labour for the soul of Palestine, could do the work of solving the mounting gulf between Palestine's Arab and Jewish communities during the British Mandate.

\section{FAir Competition}

Stewart's efforts in the 1930s and the earlier efforts of the PJS were, however, both idealistic and short-lived. While Stewart conceived of the cultural sector as a territory for consensus-building and pushed for the use of the trade fair as a unifying site for Jews and Arabs, the cultural sector and specifically the typology of the trade fair, came to be a space for political debate in the hands of Palestinian and Zionist actors. With an awareness of how soliciting economic and political engagement through international and local trade fairs could be used to move the needle on local politics, as had been modelled by both religious charitable institutions and the British colonial administration, Jews and Arabs staged trade fairs featuring artisanal handicrafts, agricultural products and industrial wares to promote their concurrent, conflicting bids for national agency in Palestine.

Leaders of the Zionist movement in Palestine had long recognised the trade fair's profound potential as a way to advance Jewish development while

\footnotetext{
${ }^{65}$ Ibid., 59.

${ }^{66}$ Ibid., 195.
} 
nurturing international support for a Jewish homeland in Palestine. Building on the successful staging of Zionist-led trade fairs in Europe and America prior to the First World War (as described in this chapter's first section), a group of local businessmen launched a Jewish trade fair in Palestine-no longer in Palestine's political and religious centre of Jerusalem, but rather in Palestine's distinctly Jewish centre, Tel Aviv. The first, embryonic exhibition of the Levant Fair in 1924, under the name "Palestine \& Near East Exhibition and Fair", was held in the same year as the British Empire Exhibition and displayed Jewish goods in two small rooms in a house on Rothschild Boulevard. When the exhibition's trio of founders, Alexander Ezer (Everserov), Abraham Eilon (Idelson), and Shlomo Jaffe had the idea of presenting a consolidated view of Jewish industrial progress in Tel Aviv, Palestine's first Jewish urban enclave was host to only 18,000 inhabitants. ${ }^{67}$ The factories on display numbered a meagre sixteen. Its mission was to present a survey of industrial progress in the yishup - which, at that point, consisted primarily of its main export industries of wine, soap and sesame-to mark the community's progress towards self-sufficiency. ${ }^{68}$

Two years later, when the founders organised a second edition of the fair, the goal was no longer "so much in showing what industrial activity was already taking place ('and that the participants were real industries by then'), but in revealing what was still lacking". ${ }^{69}$ In other words, the first exhibition took stock of the current Zionist landscape-what had the union of external capital investments and internal labour achieved together so far?-while the second edition asked a slightly more strategic question: If a Jewish nation were to come to fruition, could its internal industries sustain it? What still needed to be done? In emphatically linking the mission of the early editions of the trade fair to the yishuv's internal, autarkic ambitions, the founders managed to increase international support and ignite further economic development. By the fourth edition in 1929, the founders reported that "practically every branch of industry and some branches of agriculture" were represented at the $y i s h u v$ 's premier trade fair. ${ }^{70}$ Furthermore, the fair had achieved enough success that the Zionist trade organisation Mischar ve Taasia and the municipality of Tel Aviv (chaired by Mayor Meir Dizengoff) came on board to join in the responsibility of the fair's administration. The once-modest trade fair was now a touchstone for the yishuv's economic advancement, a strategic agent in the bid for Jewish nationhood in Palestine.

By the fair's fifth edition in 1932 its tenor had expanded from trumpeting Jewish national independence and economic growth to professing international ambitions. In addition to adopting a new "Flying Camel" logo,

67 "The Troika and the Flying Camel," n.d., 1, A458/9, Central Zionist Archive.

${ }^{68}$ Barbara J. Smith, The Roots of Separatism in Palestine: British Economic Policy, 1920-1929 (Syracuse, NY: Syracuse University Press, 1993), 161.

69 “The Troika and the Flying Camel," 3.

${ }^{70} \mathrm{Ibid}$. 
designed by the fair's resident architect Ariel El-Hanani, and selecting its official and lasting name, the "Levant Fair", the organisers expanded the fairground site, located next to the railway station in the eastern part of Tel Aviv, to host cafes, a nighttime amusement park and to host more exhibitorsincluding pavilions dedicated to the fine arts and handicrafts. The organisers established permanent fair bureaus in nine countries and appointed shortterm fair representatives in twenty-four countries to recruit foreign exhibitors and consumers. ${ }^{71}$ Foreign business participation in the fair increased by almost seven-fold between the 1929 and 1932 fairs, from 121 to 821 foreign firms. ${ }^{72}$ Along with the transformative vigour expressed by the change of name and logo, the Levant Fair organisers carved themselves a fresh image as unifiers of the industries of the Levant and as the exemplary connection point linking eastern and western markets. ${ }^{73}$ As Dizengoff articulated, foreign competition would raise the city's international profile and have the intended by-product of forcing the advancement and expansion of Jewish industry at home:

Our country which is becoming the key to the economic movement in the Near East will bind by means of these Exhibitions and Fairs the Western producers to the Eastern consumers, will improve the quality of Palestinian products and will provide markets for new labour and creation. ${ }^{74}$

Seizing an opportunity to orchestrate international trade and promote market competition as an economic centre cemented the yishuv's transformation from agricultural silo to international crossroad.

Politically active members of Palestine's Arab community resisted the Levant Fair's heroic narrative by developing their own, all-Arab trade fair in Palestine. Until the 1930s, Palestine's trade fairs both at home and abroad had been orchestrated by Zionist or British organisations, deployed as strategic tools to promote their respective political agencies in Palestine, and

\footnotetext{
${ }^{71}$ Permanent fair bureaus existed in Austria, Belgium, Egypt, France, Germany, Great Britain, Italy, Poland and Romania. Honorary fair representatives were appointed in Austria, Belgium, Bulgaria, Czechoslovakia, Denmark, Egypt, Estonia, Finland, France, Germany, Greece, Holland, Hungary, Italy, Yugoslavia, Latvia, Lithuania, Morocco, Poland, Romania, South Africa, Switzerland, Syria and the US "Report of the Fair Committee," 1932, 4, L51 \352, Central Zionist Archive.

${ }^{72}$ Ibid.

73 “The Levant Fair, in which His Excellency has taken so much interest, is intended to serve not only the twin cities of Tel Aviv and Jaffa or even Palestine alone. It is there to serve the needs of the commercial communities of the entire Middle East by offering them an unequalled opportunity for coming into contact with the latest developments in Western industry and assisting in the expansion of outlets for the produce of Middle Eastern territories." Meir Dizengoff, "Speech delivered by Mr. M. Dizengoff...At the Laying of the Foundation Stone of the Levant Fair 1934 on August 16th 1933," 2.

74 "Mayor M. Dizengoff's Speech delivered at the Opening Ceremony of the 1932 Levant Fair [in English and Hebrew]," quoted in "Report of the Fair Committee," 1932, 4.
} 
featured limited, if any, engagement by Arab businesses. The Arab Fair marked the first occasion when Palestine's Arab polity used this particular instrument of cultural, international engagement in order to serve its ethno-national, political interests.

As discussed at the beginning of this chapter, the Arab Fair came to fruition following the launch of a boycott against the 1932 Levant Fair. Through opinion pieces and editorials in local newspapers, politicians and journalists encouraged the Arab countries participating in the Levant Fair (in 1932, Egypt and Syria) to rescind their commitments and commanded Arab consumers to stay home. Ragheb Al-Nashashibi, in his role as chairman of the Palestinian Islamic Nation Conference, painted the boycott in nationalist terms, speaking as much to pan-Arab currents as Arab political ambitions inside Palestine: "The Arab nation's interest lays in abstaining from participation in order to persist on the nation's own plan towards the holy nationalist purpose" ${ }^{75}$ The head of Palestine's Arab Executive Committee, Musa Kazim Al-Husayni, promoted the boycott for its ability to protect Arab Palestinian commercial interests: "The executive committee asks the public of this dignified nation to boycott the Tel Aviv exhibition, through both participation and visiting, in order to prevent the intended damage to our nation's plan of promoting our own national manufacturing and trade". ${ }^{76}$ Amidst the rallying cries, shouted by Palestine's most established leaders, one affluent citizen, Yusuf $\mathrm{Abdu}$, had the temerity to question the utility of performing a boycott alone: "Boycott is the first weapon for fighting Zionism. If a Fair is established by the Arabs, it will be boycotted by the Jews immediately. Why not treat them reciprocally?"77 An equal and opposite reaction, a blow for a blow, would require no less than the staging of a parallel trade fair in Palestine, Abdu declared.

The newly formed executive committee of the Arab Fair, those who heeded Abdu's call to establish a trade fair representing Arab "national interests" (al-maslabat al-wataniyya), embodied the non-sectarian strain of Arab politics in the early 1930s which worked to effect politics through economics. Individual photographs of each member of the Arab Fair Committee graced the front page of Falastin on 8 July 1933, with portraits of al- 'Issa, the Arab

\footnotetext{
75 “Appeals Against Arab Participation in the Levant Fair," Falastin, 7 April 1932. This, and all subsequent quotations from the newspaper Falastin have been translated from the Arabic by the author with assistance from Manal Yousef.

${ }^{76} \mathrm{Ibid}$

${ }^{77}$ Yusuf Abdu, "Zionists and the Tel Aviv Exhibition: About Holding a National Exhibition," Falastin, 31 March 1932. I have, as of yet, been unable to uncover detailed biographical information on Yusuf Abdu. However, he is mentioned in Khalil Sakakini's diaries (an entry dated 20 March 1948), indicating Abdu was likely a member of the affluent Arab Christian community in Palestine, and perhaps a member of the family of Sakakini's wife, Sultana Abdu. Khalil Sakakini, The Diaries of Khalil Sakakini: Diaries, Letters, Reflections. Volume 8: Exile from Qatamon, 1942-52, ed. Akram Mousallam (Ramallah: Khalil Sakakini Cultural Center, Ramallah, and The Institute of Jerusalem Studies, 2010).
} 
Fair's Director, and Ahmad Hilmi Pasha, the Arab Fair's President, poised at the very top, flanking an exterior view of the Palace Hotel, the location of the Arab Fair and also current headquarters of the Supreme Muslim Council ${ }^{78}$ (Fig. 6).

The Arab Fair Committee was a joint grouping of Muslim and Christian businessmen, all of whom served on local business councils. ${ }^{79}$ Moreover, the businessmen on the Arab Fair Committee were almost exactly the same men who constituted a recently formed "National Fund" (Sanduq al-Umma), established by the joint Muslim-Christian Arab Executive Committee in 1932. The National Fund was a fundraising body, which provided the Arab Executive Committee with money for making land purchases, an institution to act as counterpart to the Jewish National Fund, which had been buying land for Jewish settlement since the late Ottoman period. ${ }^{80}$ Ahmad Hilmi Pasha was largely in control of the fund and was joined by members such as 'Omar al-Bitar (the mayor of Jaffa) and Ya'qub Bey Al-Ghusayn (leader of the nationalist Youth Congress Party) on the committee of the Arab Fair. As the group in charge of the Arab Fair, these men assured that the event would be dedicated towards furthering Palestinian political interests through non-sectarian cooperation. They also brought their interest in promoting consumption to the sphere of the cultural sector as part of the trade fair.

The Arab Fair hoped to benefit from the industrial and economic advancements of neighbouring Arab communities and make progress towards building internal industry strong enough to sustain an Arab nation in Palestine. As expressed by Yusuf Abdu,

Palestine is in great need of a national exhibition in order for the Palestinians to see the products of the neighboring countries and to have their needs covered through them. Let the relationships be strong and the commercial deals be reciprocal. This would help to realize the meaning of Arab unity. ${ }^{81}$

${ }^{78}$ Ahmad Hilmi Pasha achieved financial success as the head of the Kraman-Dik-Salti "industrial group," which ran mills and factories producing tobacco and ice, in addition to being the previous director of Muslim awqaf in Palestine and a founder of the Arab National Bank. In his business as in his politics, Ahmad Hilmi, like 'Issa al- 'Issa, was considered a true "man of the nation." Seikaly, Men of Capital, 37.

${ }^{79}$ The full Arab Fair committee, as represented by their photos, included Ahmad Hilmi Pasha, 'Issa al-'Issa, Musa Kazim Pasha al-Husayni, Mahmoud al-Da'oudi al-Dajani, 'Omar al-Bitar, Yusuf Ashur, Yusuf Talib, Ya'qub Bey al-Ghusayn, Hasan Arafeh, 'Aziz Miqati, George Sabbagh, and Hamdi Bey al-Nabulsi. Historian Nadi Abusaada also reports that as early as 14 June 1932, the Arab exhibition was registered as a private corporation with an appointed temporary Board of Directors, which at that time included Ahmad Hilmi Pasha, 'Issa al-'Issa, Hamdi Bey al-Nabulsi, Shukri al-Taji, Hasan Arafeh, 'Aziz Miqati, Hajj Taher Qarman, and Admon Rock. Abusaada, "Self-Portrait of a Nation," 127.

${ }^{80}$ For more on the formation of the National Fund, as well as its revival after the Arab Revolts of 1936-39, see Issa Khalaf, Politics in Palestine: Arab Factionalism and Social Disintegration, 1939-1948 (Albany, NY: SUNY Press, 1991), 98-104.

${ }^{81} \mathrm{Abdu}$, "Zionists and the Tel Aviv Exhibition." 


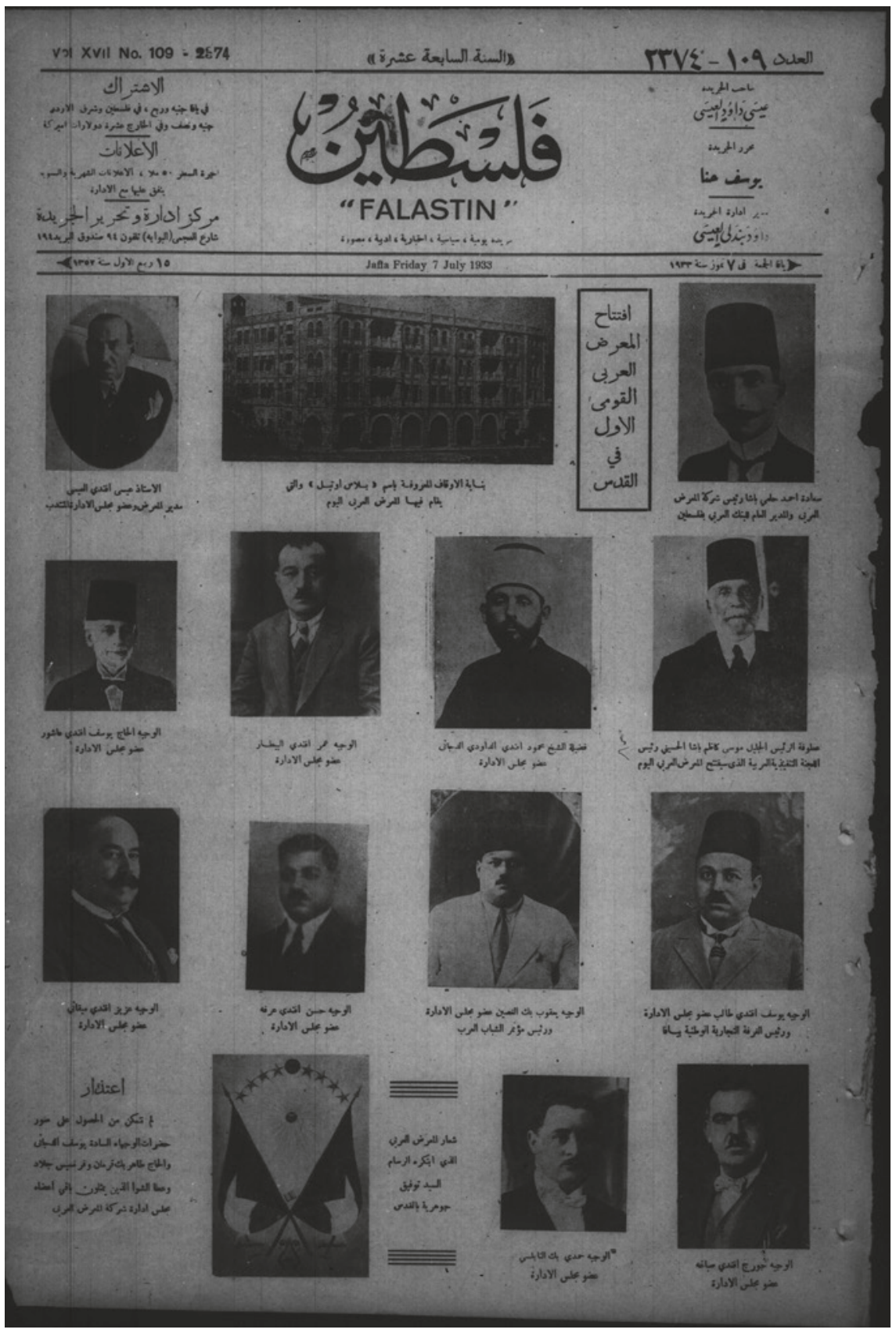

Fig. 6 Falastin, front page, 9 July 1933; image courtesy of the Institute for Palestine Studies 
The Arab Fair organisers thus only promoted the industry of Arab countries. Their stance echoed the "Encourage National Production" campaign which placed advertisements for Palestine's "national" products side by side with advertisements soliciting buyers for "Arab" products, as in the case of an advertisement for Syrian cement published in Falastin, which read,

The cement, was made of 'good Arab soil,' was 'made exclusively by Arab labor,' all stocks were owned by Arabs and there was 'no foreign (ajnabi) involvement in the firm's management. ${ }^{82}$

Such advertisements generated enthusiasm for "Arab" products among Palestine's consumers, just as the Jewish economic separatist campaign slogan, "buy only totseret ha-arets!", encouraged Palestine's Jews to "buy Jewish", as seen for example in an advertisement for the "Hebrew Banana". ${ }^{83}$

The Arab Fair's organisers predicted the trade fair would not only do the work of enhancing Arab Palestinian industry, but would also further stimulate neighbouring Arab industry and the Arab national movement at large.

Five hundred visitors attended the first day of the Arab Fair, which included visiting dignitaries from Egypt, Syria and TransJordan. ${ }^{84}$ Fittingly, the Arab Fair's opening day maintained a firm Arab presence, to the neglect of any Zionist or British administrative representation, as was reported by The Palestine Post with some dismay:

At 9 a.m. on Friday at the former Palace Hotel which was decorated with Arab colours, the Exhibition was declared open by Muza Kasim Pasha, head of the Palestine Executive. There was a noticeable absence of Government and Municipal representatives, and the only Consul present was the Egyptian, Sadiq Bey. From Syria there came Jamil Bey Mardam, once Minister of Finance and Shubri Bey, of the Nationalist Party; from Trans-Jordan, Hussein Pasha Tarawani, and several members of the Legislature; from Palestine, the Mayor of Tulkeram, Amin Bey Tamimi, and Jamal El Husseini. Only Arabic inscriptions hung outside the hotel.... an Arab hymn was played inside, and then outside, the building. After Ya'qub Bey Ghussein had opened the proceedings, a speech by Issa el Issa, editor of the 'Falastin,' was read by his brother, who stressed the fact that the Exhibition, and what it represented was the fruit of their own effort, unaided by the Government. ${ }^{85}$

${ }^{82}$ This advertisement appeared in the newspaper Falastin on 12 January 1937 and is re-printed and translated in Deborah Bernstein and Badi Hasisi, "Buy and Promote the National Cause': Consumption, Class Formation and Nationalism in Mandate Palestinian Society," Nations and Nationalism 14, no. 1 (2008): 142.

${ }^{83}$ For more on the totseret ha-arets movement, see Hizky Shoham, "Buy Local' or 'Buy Jewish"? Separatist Consumption in Interwar Palestine," International Journal of Middle East Studies 3 (2013): 469-489.

84 “First National Arab Fair," Falastin, 9 July 1933.

85 "Arab Exhibition Opened, Non-Arab Press Barred, Palestine Poorly Represented," The Palestine Post, 9 July 1933. 
A uniform message of Arab pride characterised the opening ceremonies, from the welcome speech prepared by al-'Issa to the politicians gracing the stage and the banners and music greeting visitors outside the hotel. Throughout the duration of the month-long fair, newspapers made frequent mention of visiting Arab youth groups, such as "the Moslem Scouts of Beirut" and the "Moslem boy scouts from Cairo and Alexandria", as well as Arab entertainers and athletes making appearances at the fair, such as when "Madame Asia, the Egyptian film star" came to screen two of her most recent films or when a "group of Egyptian boxers" visited the fair after competing with Tel Aviv champions in Jaffa. ${ }^{86}$ Political leaders and heads of commercial clubs from all the major neighbouring Arab countries, including Egypt, Syria, TransJordan, the Hedjaz (Saudi Arabia) and Iraq sent messages of support throughout the Arab Fair and were notable visitors, continuing the visible presence of outside Arab interest in Palestine's all-Arab Fair. ${ }^{87}$ While no precise records of attendance or revenue for the 1933 trade fair has been located, the First National Arab Fair was considered successful enough to warrant a second edition in 1934, whose opening reportedly drew in a crowd of 2000 and whose organisation, exhibits and political delegates largely mirrored the 1933 fair. ${ }^{88}$

International in its scope, the Arab Fair acted as a litmus test to evaluate the strength and welfare of the proposed Arab union. Through the establishment of the Arab Fair came a vision of an alternative political union and sphere of economic exchange to challenge the "internationalist" EuroAmerican paradigm furthered by British and Zionist agendas in Palestine-so publicly displayed at previous local and international trade fairs. Expressing his high hopes for the value of the boycott and Arab Fair, the Head of the Arab Executive Committee, Musa Kazim Al-Husayni, wrote: "We hope that the Arab Palestinian nation, affected now, will be an example of unity to the Arab nation. We hope for full unity ... to ensure the wellbeing of the whole Arab nation". ${ }^{89}$ However, by the conclusion of the both the 1934 Levant Fair and the 1934 Arab Fair, tensions between Jews and Arabs had begun

${ }^{86}$ These events were announced in The Palestine Post on the following dates in 1933: 4 July (Madame Asia), 16 July (Egyptian boxers), 17 July (Moslem Scouts of Beirut) and 26 July (Moslem boy scouts from Cairo and Alexandria).

${ }^{87}$ For example, The Palestine Post reported on 9 June 1933 that, "The Directors of the Arab Exhibition report that they have received letters from King Ibn Saud and his son, the Crown Prince, in which they wish the Exhibition success and express the wish that Hedjaz should contribute to the exhibits..." On 24 July 1933, the paper reported, "The Arab Exhibition in Jerusalem is to be visited by Ibrahim Hananu, the Syrian Nationalist member," as well as, "Hassan Shoukhri, the Mayor of Haifa, and members of the Haifa Municipality were among the visitors on Saturday to the Arab Exhibition."

88 "Arab Fair in Jerusalem Opened with Booming of Guns and Fireworks," The Palestine Post, 12 April 1934.

89 “Appeals Against Arab Participation in the Levant Fair," Falastin. 
to boil. Despite both fairs' initial successes, the Arab Uprising of 1936-1939 guaranteed the imminent collapse of both..$^{90}$

\section{Conclusion}

By surveying the rise and historical prevalence of trade fairs in Palestine directly prior to and during the British Mandate in Palestine, the dramatic narrative of Palestine's competing trade fairs of the early 1930s-the Levant Fair and the Arab Fair - can be interpreted as almost predictable, rather than anomalous. Trade fairs, a hallmark of European cultural diplomacy during the age of colonial expansion, were not reserved only as tools of vast empires nor did they come only in the aggrandised form of the world's fair. As the case of Palestine demonstrates, trade fairs could also be employed by religious, political and economic associations as instruments to stimulate more fine-grained, localised change. In order to compete in the increasingly polarised topography of Palestinian politics during the British Mandate, the Levant Fair and the Arab Fair both adopted the typology of the trade fair to speak loudly of their respective national aspirations in an increasingly raucous, uncertain, and violent terrain. Just as British Mandate officials Charles Ashbee and William Stewart had experimented with trade fairs in Palestine to control or quell local political tensions, the Levant Fair and Arab Fair organisers adopted the exhibition type in order to call government attention to and provide a forum for international support of their respective political goals.

In locating the origins of the explicitly political displays of Palestinian handicrafts in the commercial stores and international displays of Christian missionary institutions in the late 1800s, the link between Christianity and the Palestinian cultural sector comes into sharper focus. The trajectory of handicrafts' incorporation into religious missions in Palestine, outlined in the first part of the chapter, registers the integral role handicrafts played as symbols of religious charity, and later international politics. Not only did religious organisations in Palestine teach handicrafts as a form of economic charity, they also provided international religious donors with a new vehicle through which to funnel their support to Palestine and its inhabitants-a tactic which

\footnotetext{
${ }^{90}$ Both trade fairs, however, rose again. The Arab Fair ceased operation during the Arab Uprising, after the two successfully staged events in 1933 and 1934. However, in April 1945 many of the same businessmen behind the original Arab Fair staged an "Arab Industrial Fair," this time in Jaffa. The Fair was supported by the British Council and directed by Hassan Dajani. The Levant Fair was held once more, in 1936, but ceased its operations thereafter. The international involvement the Levant Fair so hoped to foster became untenable as internal tensions between Arabs and Jews increased. The Levant Fair was not revived until more than a decade after the formation of the Israeli state, in 1959. Arab Industrial Exhibition Jaffa-Palestine, April 1945, Catalogue [Arabic and English] (Jaffa: Palestine United Press, 1945), Institute for Palestine Studies Archive; Mordecai Naor and Batia Carmiel, The Flying Camel: 85 Years of Exhibitions and Fairs in Tel Aviv [Hebrew] (Tel Aviv: Eretz Israel Museum Tel Aviv, 2010), 176-235.
} 
became increasingly conspicuous in its use by Jewish philanthropic societies. In this way, late nineteenth-century religious missions and charities became drivers of Palestinian cultural production and, thereby, contributed to the Palestinian cultural sector. This new cultural sector joined the educational, agricultural and trade sectors as an equally legitimate area for international associations and political organisations to invest their efforts regarding Palestine's political future. Moreover, and as would become increasingly apparent by the time of the Levant Fair and the Arab Fair, such investments in handicraft production and display carried the potential to sway political realities on the ground

\section{BIBLIOGRAPHY}

“Appeals Against Arab Participation in the Levant Fair.” Falastin, 7 April 1932 (In Arabic).

"Arab Exhibition Opened, Non-Arab Press Barred, Palestine Poorly Represented." The Palestine Post, 9 July 1933.

"Arab Fair in Jerusalem Opened with Booming of Guns and Fireworks." The Palestine Post, 12 April 1934.

Arab Industrial Exhibition Jaffa-Palestine, April 1945, Catalogue. Jaffa: The Palestine United Press, 1945. Institute for Palestine Studies Archive (In Arabic and English).

British Empire Exhibition 1925 Official Guide. London: Fleetway Press, 1925. Brent Archives.

"First National Arab Fair." Falastin, 9 July 1933 (In Arabic).

"Handicrafts in Bethlehem." Custodia Terrae Sanctae. Accessed September 13, 2018. http://www.bethlehem.custodia.org/default.asp?id=453.

"Letter from the Secretary for Trade and Industry to Leonard Stein, WZO." 6 February 1924. S25 \11024-9-12, Central Zionist Archive.

Palestine Pavilion Handbook. London: Fleetway Press, 1925. Brent Archives.

"Report of the Fair Committee." 1932. L51 \352, Central Zionist Archive.

"Speech delivered by Mr. M. Dizengoff, O. B. E., Mayor of Tel Aviv, President of the Fair Committee, At the Laying of the Foundation Stone of the Levant Fair 1934 on August 16 $6^{\text {th }}$ 1933." 16 August 1933. L51 \351, Central Zionist Archive.

"Stein, Leonard Jacques (1887-1973), Scholar and Zionist." Oxford Dictionary of National Biography. Accessed April 1, 2019. https://doi.org/10.1093/ ref:odnb/31717.

"The Cultural and Creative Industries." UNESCO. Accessed December 20, 2018. http://www.unesco.org/new/en/santiago/culture/creative-industries/.

"The First Arab Fair." Al-'Arab, 15 July 1933 (In Arabic).

"The First Schools in the Shadows of the Sanctuaries." Custodia Terrae Sanctae. Accessed September 13, 2018. http://www.custodia.org/default.asp?id=506.

"The Troika and the Flying Camel." n.d. A458/9, Central Zionist Archive.

Abdu, Yusuf. "Zionists and the Tel Aviv Exhibition: About Holding a National Exhibition." Falastin, 31 March 1932. (In Arabic).

Abusaada, Nadi. "Self-Portrait of a Nation: The Arab Exhibition in Mandate Jerusalem, 1931-34.” Jerusalem Quarterly 77 (Spring 2019): 122-135. 
Alexander, Jacob, Cyril M. Picciotto, and Leon Simon. Zionism and the Western Jew: A Symposium Read Before the London Zionist League, on the 24th December, 1908. London: Ginzburg, 1908.

Ari, Nisa. Cultural Mandates, Artistic Missions, and "The Welfare of Palestine," 18761948. PhD diss., Massachusetts Institute of Technology, 2019.

Ashbee, C. R., ed. Jerusalem, 1918-1922; Being the Records of the Pro-Jerusalem Council during the Period of the British Military Administration. London: J. Murray, Published for the Council of the Pro-Jerusalem Society, 1921.

- "Report by Mr. C. R. Ashbee on the Arts and Crafts of Jerusalem and District.” August 1918. CRA/21/1, King's College Archives.

- "Pro-Jerusalem." The American Magazine of Art 12, no. 3 (1921): 99-102.

Bagatti O.F.M., P. Bellarmino. "L'Industria Della Madreperla a Betlemme" ("The Mother-of-Pearl Industry in Bethlehem"). In Custodia Di Terra Santa, 1342-1942, 134-152. Jerusalem: Tipografia dei Padri Francescani, 1951.

Berkowitz, Michael. "Toward an Understanding of Fundraising, Philanthropy and Charity in Western Zionism, 1897-1933." Voluntas: International Journal of Voluntary and Nonprofit Organizations: Official Journal of the International Society for Third-Sector Research 7, no. 3 (1996): 241-258.

Bernstein, Deborah, and Badi Hasisi. "Buy and Promote the National Cause': Consumption, Class Formation and Nationalism in Mandate Palestinian Society." Nations and Nationalism 14, no. 1 (2008): 127-150.

Bertz, Inka. "Trouble at the Bezalel: Conflicting Visions of Zionism and Art." In Nationalism, Zionism and Ethnic Mobilization of the Jews in 1900 and Beyond, edited by Michael Berkowitz, 247-284. Leiden and Boston: Brill, 2004.

Carmel, Alex. "The German Settlers in Palestine and Their Relations with the Local Arab Population and the Jewish Community, 1868-1918." In Studies on Palestine During the Ottoman Period, edited by Moshe Ma'oz, 442-465. Jerusalem: Magnes Press, 1975.

Cox, Catherine. "Health and Welfare, 1750-2000." In The Cambridge Social History of Modern Ireland, edited by Eugenio F. Biagini and Mary E. Daly, 261-281. Cambridge: Cambridge University Press, 2017.

Crane, Diana. The Production of Culture: Media and the Urban Arts. Newbury Park, CA: Sage, 1992.

Crawford, Alan. C. R. Ashbee: Architect, Designer \& Romantic Socialist. New Haven, CT: Yale University Press, 1985.

Crombie, Kelvin. For the Love of Zion: Christian Witness and the Restoration of Israel. London: Hodder \& Stoughton, 1991.

Cubley, Lucy Matilda. The Hills and Plains of Palestine. London: Day \& Son, 1860.

Daccarett, Enrique Yidi, Karen David Daccarett, and Martha Lizcano Angarita. El Arte Palestino de Tallar el Nácar: Una Aproximación a Su Estudio Desde el Caribe Colombiano (The Palestinian Art of Mother-of-Pearl Carving: An Approach to Its Study from the Colombian Caribbean). Bogotá: Panamericana Formas e Impresos, 2005.

Dutta, Arindam. The Bureaucracy of Beauty: Design in the Age of Its Global Reproducibility. New York: Routledge, 2007.

El-Eini, Roza. Mandated Landscape: British Imperial Rule in Palestine, 1929-1948. London and New York: Routledge, 2006.

Faucher, Charlotte. "Cultural Diplomacy and International Relations in TwentiethCentury Europe." Contemporary European History 25, no. 2 (2016): 373-385. 
Frantzman, Seth. "Education and Empowerment: Lessons and History of the Christian Education Network in Israel and Palestine." Digest of Middle East Studies 20, no. 2 (Fall 2011): 186-201.

Friedrich, Norbert, Uwe Kaminsky, and Roland Löffler, eds. The Social Dimension of Christian Missions in the Middle East: Historical Studies of the 19th and 20th Centuries. Stuttgart: Steiner, 2010.

Gardner, Gregg. The Origins of Organized Charity in Rabbinic Judaism. New York: Cambridge University Press, 2015.

Iriye, Akira. Cultural Internationalism and World Order. Baltimore, MD: Johns Hopkins University Press, 1997.

Khalaf, Issa. Politics in Palestine: Arab Factionalism and Social Disintegration, 1939 1948. Albany, NY: SUNY Press, 1991.

Malek, Jaromir. "Stewart, William Arnold (1882-1953)." Oxford Dictionary of National Biography, 2004. Accessed October 4, 2017. https://doi.org/10.1093/ odnb/9780192683120.013.38008.

Melman, Billie. Women's Orients: English Women and the Middle East, 1718-1918: Sexuality, Religion and Work. Ann Arbor: University of Michigan Press, 1995.

Murre-van den Berg, H. L., ed. New Faith in Ancient Lands: Western Missions in the Middle East in the Nineteenth and Early Twentieth Centuries. Leiden and Boston: Brill, 2006.

Naor, Mordecai, and Batia Carmiel. The Flying Camel: 85 Years of Exhibitions and Fairs in Tel Aviv. Tel Aviv: Eretz Israel Museum Tel Aviv, 2010 (In Hebrew and English).

Nye, Joseph S. Bound to Lead: The Changing Nature of American Power. New York: Basic Books, 1990.

—. "Soft Power." Foreign Policy, no. 80 (1990): 153-171.

Okkenhaug, Inger Marie. The Quality of Heroic Living, of High Endeavour and Adventure: Anglican Mission, Women, and Education in Palestine, 1888-1948. Leiden and Boston: Brill, 2002.

Perry, Yaron. British Mission to the Jews in Nineteenth-Century Palestine. London: Routledge, 2003.

Roberts, Nicholas E. "Palestine on Display: The Palestine Pavilion at the British Empire Exhibition of 1924." Arab Studies Journal 15, no. 1 (2007): 70-89.

Sakakini, Khalil. The Diaries of Khalil Sakakini: Diaries, Letters, Reflections [19071952], edited and translated by Akram Mousallam. Ramallah: Khalil Sakakini Cultural Center and The Institute of Jerusalem Studies, 2010.

Schor, Laura S. The Best School in Jerusalem: Annie Landau's School for Girls, 19001960. Waltham, MA: Brandeis University Press, 2013.

Seikaly, Sherene. Men of Capital: Scarcity and Economy in Mandate Palestine. Stanford, CA: Stanford University Press, 2016.

Shilo-Cohen, Nurit, ed. Bezalel: Crafting a Jewish Style-The Art of Bezalel, 19061996. New York: Jewish Museum, 1996.

Shoham, Hizky. "'Buy Local' or 'Buy Jewish'? Separatist Consumption in Interwar Palestine.” International Journal of Middle East Studies 3 (2013): 469-489.

Silberman, Paul. "An Investigation of the Schools Operated by the Alliance Israelite Universelle from 1862 to 1940." PhD diss., New York University, 1973.

Smith, Barbara J. The Roots of Separatism in Palestine: British Economic Policy, 19201929. Syracuse, NY: Syracuse University Press, 1993. 
Stewart, W. A. "Creative Work in Palestine: Technical and Crafts Education, 19181946." n.d. Oxford University, Griffith Institute.

The Committee of the Palestine Exhibition and Bazaar. Awakening Palestine. London: Issued by the Committee of the Palestine Exhibition and Bazaar, 1912.

The Temple Society. The Temple Society in Palestine: To Interested Visitors of the Stand of the Society at the British Empire Exhibition Wembley. London: The Temple Society, 1924.

Wallet, Bart. "Dutch National Identity and Jewish International Solidarity: An Impossible Combination? Dutch Jewry and the Significance of the Damascus Affair (1840)." In The Dutch Intersection: The Jews and the Netherlands in Modern History, edited by Yosef Kaplan, 319-330. Leiden and Boston: Brill, 2008.

Zalmona, Yigal. Tower of David Days: First Cultural Strife in Israel Art. Jerusalem: Tower of David Museum of the History of Jerusalem, 1991.

Open Access This chapter is licensed under the terms of the Creative Commons Attribution 4.0 International License (http://creativecommons.org/licenses/ by/4.0/), which permits use, sharing, adaptation, distribution and reproduction in any medium or format, as long as you give appropriate credit to the original author(s) and the source, provide a link to the Creative Commons license and indicate if changes were made.

The images or other third party material in this chapter are included in the chapter's Creative Commons license, unless indicated otherwise in a credit line to the material. If material is not included in the chapter's Creative Commons license and your intended use is not permitted by statutory regulation or exceeds the permitted use, you will need to obtain permission directly from the copyright holder.

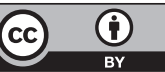

